\title{
DISCLOSURE OF ORIGIN IN THE PATENTS REGIME: A CALL TO SHIFT TOWARDS MEANINGFUL ENGAGEMENT ON MĀORI TERMS
}

\author{
Brooke Marriner*
}

\begin{abstract}
In September 2018, the Ministry of Business, Innovation and Employment (MBIE) recommended that New Zealand introduce a "disclosure of origin" requirement for patent applicants. Disclosure of origin was also recommended by the Waitangi Tribunal in 2011. If applicants were required to disclose the origin of genetic resources or traditional knowledge used, interested iwi and hapu groups would more easily be able to monitor the use of their resources and oppose patents being granted, and decide whether to challenge or oppose the grant. It would also allow more patent applications to be identified as relating to Māori interests and subsequently be referred to the Patents Māori Advisory Committee (PMAC) in the examination process. This article examines the potential for a disclosure of origin requirement in New Zealand, assessing appropriate design elements and objectives.
\end{abstract}

\section{INTRODUCTION}

The purpose of the patent system was, historically, to encourage and incentivise invention (and disclosure of inventions) by granting a patent that provided an exclusive monopoly over that invention. The patent system was never intended to protect Māori traditional knowledge (mātauranga Māori). Consequently, taonga species and mātauranga may be misappropriated in inventions without any benefits being shared with the iwi and hapū who spent decades cultivating those species and mātauranga, and without any acknowledgement of that use. Misappropriation of indigenous peoples' traditional knowledge and genetic resources has been a topic subject to much discussion in global intellectual property institutions, and in New Zealand, in recent years. In September 2018, the Ministry of Business, Innovation and Employment (MBIE) recommended that New Zealand introduce

* Law Clerk, Buddle Findlay. Submitted for the LLB (Honours) Degree, Faculty of Law, Victoria Uniersity of Wellington, 2019. Many thanks to Professor Susy Frankel for her incredibly helpful insight, guidance and supervision. 
a "disclosure of origin" requirement for patent applicants. ${ }^{1}$ Under MBIE's preferred approach, applicants would be required to disclose any genetic resources or traditional knowledge used in their invention as a formal step in the patent application process. ${ }^{2}$ A disclosure of origin requirement could have beneficial effects in New Zealand. If applicants were required to disclose the origin of genetic resources or traditional knowledge used, interested iwi and hapū groups would more easily be able to monitor the use of their resources and oppose patents being granted, and decide whether to challenge or oppose the grant. ${ }^{3}$ It would also allow more patent applications to be identified as relating to Māori interests and subsequently be referred to the Patents Māori Advisory Committee (PMAC) in the examination process. ${ }^{4}$

This article argues that a disclosure of origin requirement is not enough to create meaningful engagement with Māori in the patent system. This article will outline the need for a disclosure requirement and explain the differing approaches taken by MBIE and the Waitangi Tribunal in its Wai 262 report Ko Aotearoa Tènei: A Report into Claims Concerning New Zealand Law and Policy Affecting Māori Culture and Identity. ${ }^{5}$ Design elements for a disclosure requirement will be evaluated in light of discussions in the World Trade Organization (WTO $)^{6}$ and the World Intellectual Property Organization (WIPO); ${ }^{7}$ and obligations under relevant international treaties, such as the Agreement

1 See generally Ministry of Business, Innovation and Employment Discussion paper: Disclosure of origin of genetic resources and traditional knowledge in the patents regime (September 2018).

2 See generally MBIE, above $\mathrm{n} 1$.

3 See generally Waitangi Tribunal Ko Aotearoa Tēnei: A Report into Claims Concerning New Zealand Law and Policy Affecting Māori Culture and Identity - Te Taumata Tuatahi (Wai 262, 2011) [Ko Aotearoa Tēnei: Te Taumata Tuatahi] at 91-93; and Waitangi Tribunal Ko Aotearoa Tēnei: A Report into Claims Concerning New Zealand Law and Policy Affecting Māori Culture and Identity: Te Taumata Tuarua (Wai 262, 2011) vol 1 [Ko Aotearoa Tènei: Te Taumata Tuarua vol 1] at 203-204.

4 See generally Ko Aotearoa Tēnei: Te Taumata Tuatahi, above n 3, at 91-93; and Ko Aotearoa Tēnei: Te Taumata Tuarua vol 1, above n 3, at 203-204.

5 See generally Ko Aotearoa Tènei: Te Taumata Tuatahi, above n 3.

6 See generally The protection of traditional knowledge and folklore WTO Doc IP/C/W/370/Rev.1 (9 March 2006); Review of the provisions of Article 27.3(b). Summary of issues raised and points made WTO Doc IP/C/W/369/Rev.1 (9 March 2006); and The relationship between the TRIPS Agreement and The Convention on Biological Diversity WTO Doc IP/C/W/368/Rev.1 (8 February 2006).

7 See generally Intergovernmental Committee on Intellectual Property and Genetic Resources, Traditional Knowledge and Folklore Disclosure of Origin or Source of Genetic Resources and Associated Traditional Knowledge in Patent Applications WIPO/GRTKF/IC/20 (17 October 2011). This also included discussions within the WIPO Intergovernmental Committee on Intellectual Property and Genetic Resources, Traditional Knowledge and Folklore (WIPO-IGC): Intergovernmental Committee on Intellectual Property and Genetic Resources, Traditional Knowledge and Folklore Consolidated Document Relating to Intellectual Property and Genetic Resources Rev.2, prepared by the Secretariat WIPO/GRTKF/IC/36/4 (10 April 2018) [IGC Draft Articles]; and Intergovernmental Committee on Intellectual Property and Genetic Resources, Traditional 
on Trade-Related Aspects of Intellectual Property Rights (TRIPS Agreement) ${ }^{8}$ and the Convention on Biological Diversity (CBD), ${ }^{9}$ before assessing whether evidence of access and benefit-sharing (ABS) arrangements should be provided. This article concludes that in a New Zealand context, the options suggested by MBIE are inadequate without other measures being taken in conjunction. In order to have a meaningful effect, engagement with iwi and hapū must be on Māori terms. The author suggests implementing the recommendations made by the Waitangi Tribunal in Ko Aotearoa Ténei by: introducing a bioprospecting regime; ensuring that the PMAC is explicitly able to advise on patentability and exceptions, particularly the risk to kaitiaki; giving the Commissioner of Patents explicit power under the ordre public (public policy) exception to refuse a patent if it would damage the kaitiaki relationship; giving iwi and hapū the opportunity to register kaitiaki interests and mātauranga; and requiring patent applicants to disclose the taonga species and mātauranga used in their inventions to enable kaitiaki to identify applications that run counter to their obligations. ${ }^{10}$

\section{THE NEED FOR A DISCLOSURE REQUIREMENT}

\section{A The Intellectual Property System and Mätauranga Māori}

The western legal system was founded on allocating "bundles of rights" over resources to enable exploitation. ${ }^{11}$ A person who has the right to use a resource holds that right exclusively. ${ }^{12}$ Exclusive rights can be sold and traded for other resources, typically money. That same concept was applied to intangible resources - intellectual property. ${ }^{13}$ For example, a person who invents something that is novel, useful and involves an inventive step can be granted a patent. ${ }^{14}$ Patents confer exclusive rights over that invention for 20 years. ${ }^{15}$

Knowledge and Folklore WIPO Technical Study on Patent Disclosure Requirements Related to Genetic Resources and Traditional Knowledge (Study No 3, 2004).

8 Marrakesh Agreement Establishing the World Trade Organization 1867 UNTS 3 (opened for signature 15 April 1994, entered into force 1 January 1995), Annex 1C (Agreement on Trade-Related Aspects of Intellectual Property Rights) [TRIPS Agreement].

9 Convention on Biological Diversity 1760 UNTS 79 (opened for signature 5 June 1992, entered into force 29 December 1993) [CBD], art 1.

10 Ko Aotearoa Tēnei: Te Taumata Tuarua vol 1, above n 3, at 200-205.

11 Brian Garrity "Conflict Between Maori and Western Concepts of Intellectual Property" (1999) 8 Auckland U L Rev 1193 at $1193-1194$.

12 At 1194.

13 At 1194.

14 Patents Act 2013, ss 6,7 and 10.

15 Section 20. 
The concept of ownership does not neatly align with te ao Māori (the Māori world). While this paper discusses Māori concepts and interests in a general sense, it should be acknowledged that te ao Māori, tikanga and mātauranga Māori differ across iwi (tribes) and hapū (descent groups). The generalisation in this paper is not intended to undermine those differences but is done in the interests of brevity. In te ao Māori, rights over resources are collective. In fact, framing these as "rights" is not entirely accurate. Te ao Māori is derived from and based on the natural environment. ${ }^{16}$ Different iwi and hapu groups have drawn their culture, identity, and knowledge from natural resources around them, such as land, waterways, plants, and wildlife. ${ }^{17}$ Māori have whakapapa (genealogy) with those natural resources and consider them to be taonga (treasures). ${ }^{18}$ The mātauranga that has evolved from and is associated with those resources is also taonga. ${ }^{19}$ Because of the relationship of whakapapa with these taonga resources, Māori have the right to utilise them, but are also obliged to nurture and care for their physical wellbeing and mauri (spiritual wellbeing) ${ }^{20}$ This is better framed as a give and take relationship as opposed to an ownership right, and is referred to as kaitiakitanga (guardianship). The give and take relationship is collective in the sense that every iwi and hapu that has whakapapa with the resources is a kaitiaki (guardian). ${ }^{21}$

Having rights in western intellectual property systems means owning intellectual creations. ${ }^{22}$ It is based on the idea that society generally benefits from intellectual creation, and incentivises that creation by protecting its fruits. ${ }^{23}$ But this is balanced against matters of public interest. To contrast, Māori tend to view ideas as flowing from relationships with taonga; whenua (land); whakapapa; and wairua (spirit), rather than the product of an individual's innovation and creativity. ${ }^{24}$ Those ideas would be protected in te ao Māori by tapu (to be sacred; prohibited; protected) and were passed down collectively through iwi and hapū. ${ }^{25}$ These two systems are incompatible in many ways. Western intellectual property rights focus on creation in order to reward inventors through economic rights, whereas mātauranga cannot be "attributed" in an ownership sense to any one creator, or group of

16 Ko Aotearoa Tènei: Te Taumata Tuatahi, above n 3, at 23.

17 At 23.

18 At 23.

19 At 23 .

20 At 23 .

21 At 23.

22 Garrity, above n 11, at 1200.

23 At 1201; and Susy Frankel "Lord Cooke and Patents: The Scope of 'Invention'" (2008) 39 VUWLR 73 at 8687.

24 Tania Waikato "He Kaitiaki Mātauranga: Building a Protection Regime for Māori Traditional Knowledge" (2005) 8 YBNZ Juris 344 at 347-353; and Garrity, above n 11, at 1202.

25 Garrity, above n 11, at 1204-1205. 
creators. ${ }^{26}$ Intellectual property rights are given for fixed terms (such as patents for 20 years), whereas Māori cultural rights are perpetual. ${ }^{27}$ And because information is inherited through generations, it is not usually considered novel - a requirement for patent protection. ${ }^{28}$ Not only does the western intellectual property system fail to protect Māori intellectual property, it enables that property to be misappropriated by individuals other than the traditional Māori owners. ${ }^{29}$

The first patent in New Zealand was granted in 1861. The specification included a manufacturing process to use harakeke (flax) - a taonga species of cultural significance for Māori. ${ }^{30}$ The patent specification included no mention of existing Māori practice, or the mātauranga that assisted in identifying the potential benefits and uses of harakeke as a material. ${ }^{31}$ This issue is not unique to New Zealand: misappropriation of traditional knowledge and taonga plant species has been a concern for many indigenous peoples globally. The next sections of this paper will discuss how the patent system, both globally and in New Zealand, has enabled misappropriation.

\section{B Misappropriation in the Patent System}

Misappropriation of indigenous peoples' traditional knowledge and genetic resources is an issue that has been subject to extensive discussion at WIPO for just under two decades. ${ }^{32}$

Genetic resources are "the genetic material of plants, animals or micro-organisms that have, or may have, value to us." ${ }^{33}$ Traditional knowledge includes: ${ }^{34}$

... the know-how, practices, skills, and innovations of indigenous peoples and local communities, resulting from intellectual activity in a traditional context. It occurs in a variety of contexts, and may be agricultural, scientific, technical, ecological, medicinal, biodiversity-related and more. Traditional

26 Waikato, above n 24, at 347-353; and Garrity, above n 11, at 1204-1205.

27 Waikato, above n 24, at 347-353; and Garrity, above n 11, at 1206. For a discussion of the issue in the Caribbean context see Sharon B Le Gall "Defining Traditional Knowledge: A Perspective from the Caribbean" (2012) 58(4) Caribbean Quarterly 62 at 67-68.

28 Garrity, above n 11, at 1206.

29 Waikato, above n 24; and Garrity, above n 11.

30 For a discussion on the patent grant see "Designing the Future - Celebrating the Past" (2011) 3 WIPO Magazine 25. For a discussion on the cultural importance of harakeke see Waitangi Tribunal Ko Aotearoa Tēnei: Te Taumata Tuatahi, above n 3, at 65-66.

31 Susy Frankel and Jessica C Lai Patent Law and Policy (LexisNexis, Wellington, 2016) at 23-24.

32 See generally IGC Disclosure of Origin or Source of Genetic Resources, above n 7; IGC Draft Articles, above n 7; and IGC WIPO Technical Study, above n 7.

33 MBIE, above $\mathrm{n} 1$, at 1 .

34 At 1. 
knowledge may be associated with genetic resources and, in some cases, molecules, properties and/or active ingredients of genetic resources have been identified with the support of traditional knowledge.

Indigenous groups have expressed concerns that their traditional knowledge and genetic resources have been utilised by non-indigenous groups in patented inventions. ${ }^{35}$ Indigenous groups may spend decades, centuries or millennia cultivating and protecting plant species, and traditional knowledge associated with them. ${ }^{36}$ Big corporations will invest money in searching for genetically useful biological resources (usually for use in pharmaceutical or agricultural produces). ${ }^{37}$ This practice is referred to as bioprospecting. Traditional knowledge can reduce the randomness and cost of bioprospecting ${ }^{38}$ by providing information on the uses of different plant species, whether that includes effective methods of cultivation or harvest for food; ${ }^{39}$ uses for medicinal or healing purposes; ${ }^{40}$ or as a fabric, ${ }^{41}$ to name a few examples. ${ }^{42}$ Research and development is undertaken by those corporations to discover, isolate and use the chemical compounds in the plant's DNA that contribute to its medicinal, material or agricultural properties. ${ }^{43}$ That discovery or invention may then be patented by corporations or individuals that are not part of the indigenous group that cultivated the resources and

35 See WTO The protection of traditional knowledge and folklore, above n 6; WTO Review of the provisions of Article 27.3(b), above n 6; and WTO The relationship between the TRIPS Agreement and The Convention on Biological Diversity, above n 6.

36 Jonathan Curci The Protection of Biodiversity and Traditional Knowledge in International Law of Intellectual Property (Cambridge University Press, Cambridge, 2010) at 5-6.

37 Ko Aotearoa Tēnei: Te Taumata Tuatahi above n 3, at 72.

38 Verity Dawkins "Combating biopiracy in Australia: Will a disclosure requirement in the Patents Act 1990 be more effective than the current regulations?" (2018) 21 J World Intellect Prop 15 at 17; and Ko Aotearoa Tènei: Te Taumata Tuatahi, above n 3, at 72.

39 See for example the discussion on the use of agricultural techniques in basmati rice lines and the distinctive yellow colour of the Enola bean in Paul Kuruk "Regulating Access to Traditional Knowledge and Genetic Resources: The Disclosure Requirement as a Strategy to Combat Biopiracy" (2015) 17 San Diego Int'l LJ 1 at $13-18$.

40 For example mānuka has antihistimane, antibacterial and antifungal properties and has been used to treat many skin conditions, and more recently post-surgical treatments. See this use discussed in Ko Aotearoa Tēnei: Te Taumata Tuatahi, above n 3, at 66. See also the use of turmeric for wound healing discussed in Kuruk, above n 39, at 12-13.

41 For example harakeke (flax) has been investigated for its potential as a clothing fabric. See this use discussed in Waitangi Tribunal Ko Aotearoa Tēnei: Te Taumata Tuatahi, above n 3, at 65-66.

42 Ko Aotearoa Tēnei: Te Taumata Tuatahi, above n 3, at 72.

43 Valentina Tejera "Tripping over Property Rights: Is It Possible to Reconcile the Convention on Biological Diversity with Article 27 of the TRIPs Agreement" (1999) 33 New Eng L Rev 967 at 971. 
knowledge. Misappropriation can be problematic for indigenous peoples that cannot afford to, or have no interest in, commercialising their genetic resources and traditional knowledge. ${ }^{44}$

Firstly, patents may be granted without any acknowledgement of the genetic resources or traditional knowledge utilised, and without any benefits being shared with the indigenous group who cultivated those resources or knowledge. In some cases, genetic resources or traditional knowledge may be accessed or utilised without consent. This ignores the valuable contribution indigenous groups made to those inventions, and ensures that any economic benefit is enjoyed only by the patent holder and investors in the invention.

Secondly, in some cases this could lead to patents being granted that result in economic disadvantage to those indigenous groups. ${ }^{45}$ Consider, for example, the Enola bean. An individual purchased a bag of yellow beans while in Mexico and began a selective breeding programme once they returned to the United States. ${ }^{46}$ Two years later, a "new" field bean variety was patented. ${ }^{47}$ It was considered novel due to its distinctive yellow colour that had never been grown in the United States. ${ }^{48}$ The patent claim covered the yellow bean seed; the plants produced by it; all of the other plants with the same physiological and morphological characteristics; and the breeding methods employed. ${ }^{49}$ The patent holder requested royalty payments on all imports of beans from Mexico that were caught within the patent claim. ${ }^{50}$ Exports from Mexico reduced by 90 per cent, affecting over 22,000 farmers. ${ }^{51}$ The patent claim was later rejected, but the system had already permitted a monopoly that had destroyed competition for almost 10 years. ${ }^{52}$

Finally, misappropriation enables a form of colonisation. The knowledge of indigenous groups is often unable to be protected by intellectual property law because it is not new; it is not original; it may be collectively held; and because intellectual property rights are granted for fixed terms, but traditional knowledge is typically viewed as perpetual. ${ }^{53}$ The first party to explain that knowledge or resource in the terms required by western intellectual property systems is awarded exclusive rights over that

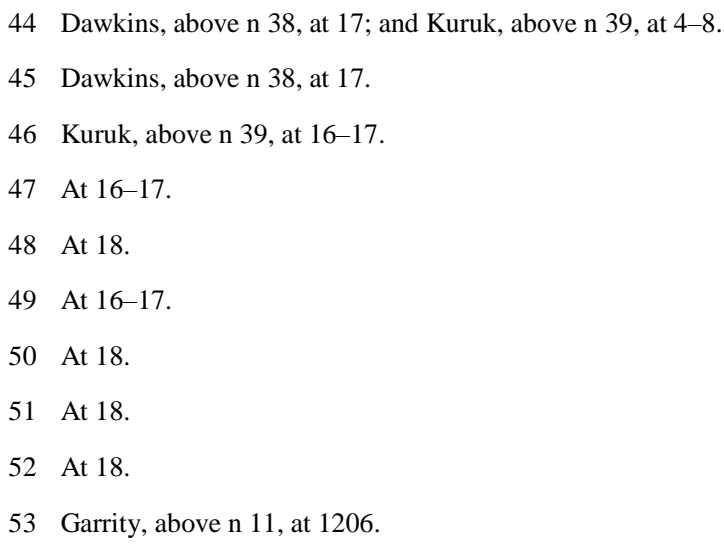


"invention". ${ }^{54}$ Consequently, the patent system may be considered a tool for neo-colonialism that the system and its requirements ignore. ${ }^{55}$ Many indigenous peoples have experienced their rights being disregarded and neglected by colonial systems as their resources are plundered. ${ }^{56}$ Patents that involve traditional knowledge may be another example of that.

As a consequence, there have been calls for international action to counter misappropriation of genetic resources and traditional knowledge. ${ }^{57}$ Protecting traditional knowledge is in the common interest of all parties; because of its value as a resource, it must be preserved, and the owners of traditional knowledge should benefit from its use. ${ }^{58}$ One method of addressing misappropriation is requiring patent applicants to disclose any traditional knowledge or genetic resources utilised in their invention.

\section{Patent System in New Zealand}

\section{The patent application process}

New Zealand patent law is governed by the Patents Act 2013. The purpose of the Act is outlined in s 3 and includes ensuring that a patent is only granted in appropriate circumstances, ${ }^{59}$ and aims to "address Māori concerns relating to the granting of patents for inventions derived from indigenous plants and animals or from Māori traditional knowledge". ${ }^{60}$

Patent applications are made to the Intellectual Property Office of New Zealand (IPONZ). ${ }^{61}$ Applicants are required to complete a patent specification which includes a technical description of the invention and the claim (boundaries) of the patent requested. ${ }^{62}$ Part 2 of the Patents Act outlines patentability criteria: inventions must be novel; ${ }^{63}$ involve an inventive step; ${ }^{64}$ and must be useful. ${ }^{65}$

54 Ko Aotearoa Tēnei: Te Taumata Tuatahi, above n 3, at 85.

55 Alison L Hoare and Richard G Tarasofsky "Asking and Telling: Can 'Disclosure of Origin' Requirements in Patent Applications Make a Difference" (2007) 10 J World Intellect Prop 149 at 159.

56 At 159

57 WTO The protection of traditional knowledge and folklore, above n 6, at 9.

58 At 9 .

59 Section 3(b).

60 Section $3(d)$.

61 New Zealand Intellectual Property Office "Apply for a patent" <www.iponz.govt.nz>.

62 New Zealand Intellectual Property Office, above n 61.

63 Patents Act, s 6.

64 Patents Act, s 7.

65 Patents Act, s 10. 
This means considering whether the invention is already within the prior art base, ${ }^{66}$ and whether the invention is "not obvious" to a person skilled in the art. ${ }^{67}$ The prior art base includes all matter that, before the priority date, has been made available to the public by written or oral description or any other use. ${ }^{68}$ There are also exceptions to patentability: inventions contrary to ordre public ${ }^{69}$ or morality are not patentable. ${ }^{70}$ Examples provided in the Act are mostly related to uses of human genetic material. ${ }^{71}$ In the patent examination process, the Commissioner of Patents will need to be satisfied on the balance of probabilities that the application meets patentability criteria; has complied with requirements under the Act; and there is no lawful objection to granting the patent. ${ }^{72}$ Third parties are able to submit to IPONZ challenging the grant of a patent on the basis that it does not meet patentability requirements. ${ }^{73}$ Any objections are included in the examination report. ${ }^{74}$ If granted, a patent will give exclusive rights over the content of the patent claim.

On its face, it may appear that mātauranga Māori would not be patentable on the grounds that it forms part of the prior art base. It is true that if a patent claim were capable of preventing uses of traditional knowledge, it could likely be challenged on the basis of prior art. ${ }^{75}$ However, an inventive step can often be achieved by commercialising and developing a marketable form of traditional knowledge. ${ }^{76}$ Consequently, it is possible to be granted a patent that utilises misappropriated traditional knowledge and genetic resources. Further, there have been criticisms that New Zealand's patent examination process is poor, and that non-indigenous parties have been able to obtain patents based on traditional knowledge even in cases where they should have been rejected for lacking novelty and non-obviousness. ${ }^{77}$ While mātauranga itself is not patentable, derivations from mātauranga Māori

66 Patents Act, s 6.

67 Patents Act, s 7.

68 Patents Act, s 8.

69 The term used in the Patents Act is public order but is attributed the same meaning as ordre public in the TRIPS Agreement, which is akin to "social policy". Consequently, this paper uses that term for coherence and certainty.

70 Patents Act, s 15.

71 Section 15.

72 Patents Act, s 65.

73 Patents Act, s 95; and New Zealand Intellectual Property Office "Examination process" $<w w w . i p o n z . g o v t . n z>$.

74 New Zealand Intellectual Property Office, above n 73.

75 Jessica C Lai "Māori Traditional Knowledge and New Zealand Patent Law: The 2013 and the Dawn of a New Era" (2014) 17 J World Intellect Prop 34 at 36.

76 At 36 .

77 Lai, above n 75, at 36-37; and Ko Aotearoa Tēnei: Te Taumata Tuarua vol 1, above n 3, at 170. 
or taonga resources can be. For example, the Waitangi Tribunal has pointed out that the process for using poroporo to darken grey hair is not patentable; because it is already known to a section of the community, it is not novel. ${ }^{78}$ It might, however, be possible to obtain protection for the process of isolating the substance that darkens hair, or for the isolated substance itself. ${ }^{79}$ In this way, patents may be granted over uses of mātauranga or taonga species.

\section{The Patents Māori Advisory Committee}

If the Commissioner of Patents requests it, the Patents Māori Advisory Committee (PMAC) may give advice on whether an invention is derived from mātauranga Māori or indigenous plants or animals, and whether commercial exploitation of that invention is likely to be contrary to Māori values. ${ }^{80}$ This advice is relevant to both factors; derivation from mātauranga or taonga plant species may go towards patentability criteria, but offense to Māori values may also be a basis for concluding that the patent would be counter to ordre public ${ }^{81}$ or morality. ${ }^{82}$ The Waitangi Tribunal has argued that Māori interests go to the fundamentals of society: New Zealand's "identity, character, and institutions". ${ }^{83}$ Despite this, there is no clear link between this advisory role and ordre public or morality. The Commissioner must take the PMAC's advice into account. ${ }^{84}$

The PMAC was introduced in the 2013 amendment to the Patents Act. This appears to address Māori concerns relating to the granting of patents for inventions derived from indigenous plants or animals of Māori traditional knowledge, as outlined in the purpose section of the Act, but the PMAC's powers are limited. For one, the PMAC is only able to provide advice on a patent application if it is referred by the Commissioner of Patents. ${ }^{85}$ Referral depends on the Commissioner's ability to ascertain which applications are of concern to Māori, yet the terms used are broad and vague - what are "Māori values"? ${ }^{86}$ Further, most patent examiners are trained in western intellectual property law and are not knowledgeable about mātauranga or tikanga Māori. ${ }^{87}$ It would be difficult for examiners

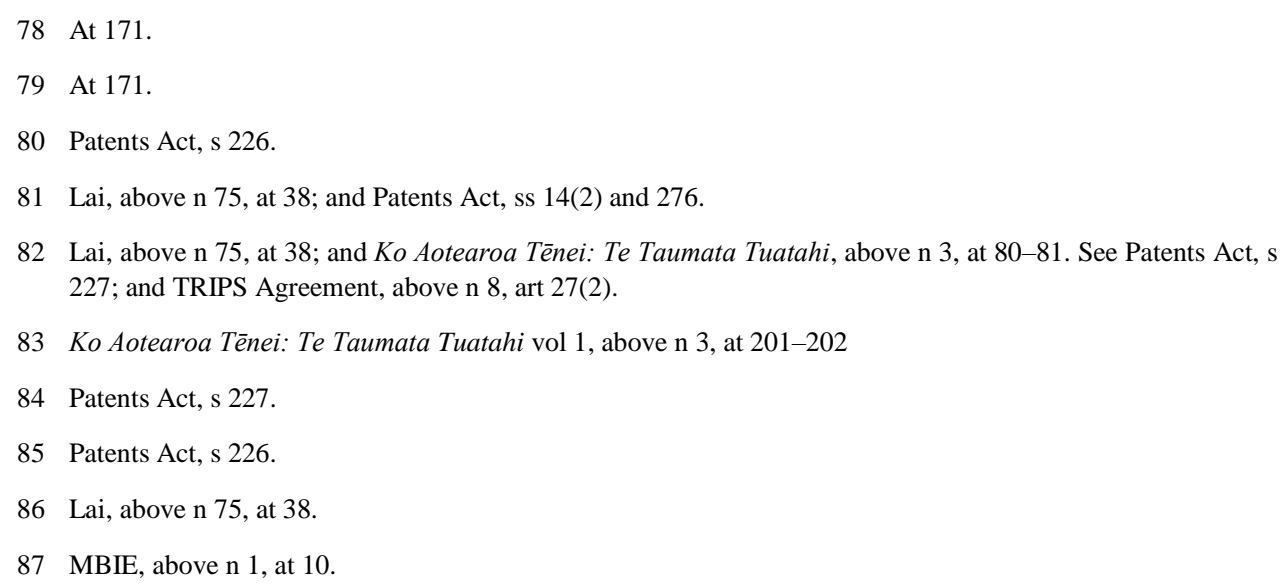


to identify tikanga-based concerns, and even more difficult to identify instances of prior Māori art. ${ }^{88}$ This is especially so in cases where knowledge is secret, or not well published. ${ }^{89}$ Its advice is not binding, ${ }^{90}$ though the majority of Māori advisory bodies, and even the Waitangi Tribunal are not. Finally, te ao Māori, tikanga and mātauranga Māori differ across iwi and hapū groups, of which there are many. It would be impossible for Commissioners to identify the knowledge and values of all iwi and hapū. ${ }^{91}$ Expecting the PMAC to be able to do this is an example of essentialism of Māoritanga and sends the message that the PMAC is a political statement rather than a mechanism to protect Māori from misappropriation of their taonga resources and mātauranga.

As of September 2018, the PMAC had disappointingly not yet been referred to for advice. ${ }^{92}$ There have likely been patent applications that should have been referred to the PMAC but were not, because they were not identified as relevant. ${ }^{93}$ The New Zealand system is not fit for addressing Māori concerns about patents relating to indigenous plans or from mātauranga Māori. In light of this, MBIE has released an options paper on implementing a disclosure of origin requirement in the New Zealand patents regime.

\section{THE NEW ZEALAND APPROACH TO DISCLOSURE OF ORIGIN}

\section{A The Ministry of Business, Innovation and Employment (MBIE's) Preferred Approach}

\section{The options}

MBIE is currently ${ }^{94}$ considering introducing a disclosure of origin requirement to New Zealand's patents regime. The problems identified with the existing regime were that patent applications may not be recognised as relevant to Māori, and consequently may not be referred to the PMAC for advice and that there is little information available about the use of traditional knowledge (particularly mātauranga Māori) and genetic resources in research. ${ }^{95}$ In a discussion paper released in September 2018, MBIE outlined three options for consideration: a basic; a medium; and a strong mandatory
88 At 10 .
89 Lai, above n 75 , at 38 .
90 Patents Act, s 227.
91 Lai, above n 75, at 40 .
92 MBIE, above $\mathrm{n} 1$, at 10
93 At 10.
94 As of late 2020.
95 MBIE, above n 1, at 10. 
disclosure requirement. ${ }^{96} \mathrm{~A}$ basic disclosure requirement would require a patent applicant to disclose the country of origin of any genetic resources or traditional knowledge used in the invention. ${ }^{97}$ The Waitangi Tribunal defined "used" as synonymous to "based" or "derived": anything that may have prompted that course of research. ${ }^{98}$ Applicants would have the option of declaring that they did not know the origin of genetic resources or traditional knowledge used. ${ }^{99}$ The requirement would be procedural. Patent applicants would be required to disclose any traditional knowledge or genetic resources used in the invention in order to proceed with the application, but would not need to provide any detail on their use. ${ }^{100}$ If a disclosure or declaration had been made, IPONZ could proceed with reviewing the application - if not, the examination process would be paused. ${ }^{101}$ The applicant would be required to complete disclosure before proceeding. ${ }^{102}$ IPONZ would not investigate the terms of use or access, or the veracity of disclosure. ${ }^{103}$

A medium mandatory disclosure requirement would be the same, but if the applicant did not know the origin of genetic resources or traditional knowledge used, they could instead disclose the source (for example, the gene bank or ex situ collection). ${ }^{104}$ To comply with the strong disclosure requirement, a patent applicant would be required to provide evidence of compliance with the ABS requirements of the country of origin. ${ }^{105}$ In effect, this would consist of proving contractual, licensing or certification arrangements. If evidence was not provided, IPONZ could refuse the application or revoke the patent, irrespective of whether the invention otherwise met patentability criteria. ${ }^{106}$ This is a substantive requirement, because it can affect the outcome of an application.

\author{
96 At $13-14$. \\ 97 At 13 . \\ 98 Ko Aotearoa Tēnei: Te Taumata Tuarua vol 1, above n 3, at 204, as cited in MBIE, above n 1, at 23. \\ 99 MBIE, above $\mathrm{n} 1$, at 13. \\ 100 At 13. \\ 101 At 13 . \\ 102 At 13 . \\ 103 At 13. \\ 104 At $13-14$. \\ 105 At 14. \\ 106 At 14.
}




\section{MBIE's evaluation}

MBIE's preferred approach, prior to consultation, was a medium mandatory disclosure requirement. ${ }^{107}$ The primary objectives MBIE evaluated its options against were to: ${ }^{108}$

(a) Aid better-quality decision-making in the patents regime.

(b) Obtain quality information about the use of traditional knowledge and genetic resources in research.

(c) Minimise compliance and administrative costs.

(d) Ensure New Zealand is aligned with its international obligations and interests.

The first two objectives were prioritised over the latter two, as they were more closely related to the issues MBIE identified. ${ }^{109}$ In saying that, MBIE discussed all objectives when considering its preferred approach. All disclosure requirements would increase the information provided to IPONZ, contribute to ensuring relevant applications referred to the PMAC and assist in avoiding the grant of erroneous patents. ${ }^{110}$ A strong disclosure requirement would be the most effective in aiding better quality decision-making in the patents regime because, under the basic and medium disclosure requirements, an applicant would have the option to declare that the origin of genetic resources or traditional knowledge is unknown. ${ }^{111}$ The medium requirement would generate more information than the basic, requiring the applicant to still disclose the source of the resources or knowledge. ${ }^{112}$ In contrast, an applicant would not be granted a patent under the strong disclosure requirement without disclosing the country of origin, increasing IPONZ's ability to identify applications relating to Māori interests. ${ }^{113}$

Evidence of ABS or prior informed consent could support the patentability criteria of novelty or inventive step. ${ }^{114}$ Despite this, MBIE reasoned that requiring evidence of ABS would primarily benefit foreign countries and their indigenous peoples rather than New Zealand or Māori. ${ }^{115}$ This conclusion was based on economic factors. MBIE noted that New Zealand would benefit more from "major economies with high volumes of pharmaceutical and biotechnology patents", such as the

107 At 19

108 At 12.

109 See discussion above in Part III(A)(1); and MBIE, above n 1, at 12.

110 MBIE, above $\mathrm{n} 1$, at $14-15$.

111 At 15 .

112 At 15.

113 At 15 .

114 At 15

115 At 20. 
United States, introducing a disclosure of origin requirement. ${ }^{116}$ New Zealand genetic resources are often used in such inventions; a disclosure requirement in those jurisdictions would potentially alter research practices, incentivising researchers based in those countries to obtain prior informed consent from and share economic benefits with iwi and hapū. ${ }^{117}$ Even if the strong disclosure requirement was implemented, New Zealand does not have an ABS or bioprospecting regime in place, and applicants consequently would be under no obligation to disclose ABS arrangements with Māori. ${ }^{118}$

MBIE reasoned that a medium disclosure would be the most effective in obtaining quality information about the use of genetic resources and traditional knowledge in research; if the origin was unknown to the applicant, basic disclosure would not provide any information. ${ }^{119}$ The strong disclosure would make the patent application process more onerous. ${ }^{120}$ MBIE was concerned that because patents are not the only method of commercialising traditional knowledge and genetic resources, an onerous application process would lead to inventions being commercialised in other ways. ${ }^{121}$ Given the relative size of New Zealand in the international market, inventors may simply apply for patents in other jurisdictions or forego patent protection altogether. ${ }^{122}$ Equally, investors may instead rely on non-disclosure intellectual property protection mechanisms such as trade secret protection. ${ }^{123}$ IPONZ would be unable to gather any general information about the use of genetic resources and traditional knowledge in research (one of the objectives identified in the review), and iwi and hapū would be unable to identify and trace uses of their mātauranga and taonga resources. ${ }^{124}$ These are two of the major benefits of a disclosure requirement.

MBIE commissioned Castalia Strategic Advisors to undertake an economic analysis. Castalia considered the additional application time, legal fees and compliance costs for applicants. ${ }^{125}$ A strong disclosure requirement would result in significantly higher cost. ${ }^{126}$ However, even for the strong

116 At 20.

117 At 20.

118 At 20.

119 At $15-16$.

120 At $15-16$.

121 At $15-16$.

122 Martin A Girsberger "Transparency Measures under Patent Law regarding Genetic Resources and Traditional Knowledge: Disclosure of Source and Evidence of Prior Informed Consent and Benefit-'Sharing'" (2004) 7 J World Intellect Prop 451 at 480; and Dawkins, above n 38, at 27.

123 IGC WIPO Technical Study, above n 7, at 67.

124 MBIE, above $n 1$, at $15-16$.

125 At 16.

126 At 17. 
requirement, this would only amount to an additional $\$ 19.85$ per application, or approximately $\$ 3.50$ for the basic and medium requirements. ${ }^{127}$ Additional administrative costs for IPONZ were also identified, including implementation; updating procedures and policy; additional training; and additional processing time. ${ }^{128}$ Both the basic and medium requirements were preferred in this respect. ${ }^{129}$ Overall, MBIE reasoned that the costs for the medium requirement were relatively low, and the "intangible benefits" of increasing the volume and quality of information; complying with Treaty of Waitangi obligations; and a clearer international position outweighed those costs. ${ }^{130}$ However, in the Castalia report, benefits to Māori were considered unquantifiable, and consequently outside the scope of the paper. ${ }^{131}$ It is also interesting to note that aligning with international obligations and interests and gathering quality information about the use of genetic resources and traditional knowledge in research were both, in MBIE's view, objectives of the disclosure of origin requirement, but compliance with Treaty obligations was not, ${ }^{132}$ despite this being identified as a potential objective in the Castalia report. ${ }^{133}$ Instead, MBIE's report seems to focus on the potential economic benefits that New Zealand could enjoy by introducing a disclosure requirement, such as reciprocal international relationships.

Finally, MBIE considered that none of the options were inconsistent with international obligations under the TRIPS Agreement or any of the free trade agreements New Zealand is a party to. ${ }^{134}$ All three options would better fulfil New Zealand's obligations under the Convention on Biological Diversity (CBD), but given its requirement to disclose evidence of ABS arrangements, a strong disclosure requirement would be the most consistent. ${ }^{135}$ Overall, MBIE preferred the medium disclosure requirement because it would be the most effective in ensuring that quality information on the use of genetic resources and traditional knowledge in research was gathered. ${ }^{136}$ While the strong

127 At 17.

128 At 17 .

129 At $18-20$.

130 At $18-20$.

131 Castalia Strategic Advisors Economic Evaluation of Disclosure of Origin Requirements: Report to Ministry of Business, Innovation and Employment (April 2018) at 14.

132 Ministry of Business, Innovation and Employment Summary of submissions on Disclosure of origin of genetic resources and traditional knowledge in the patents regime: discussion paper (2019) at 2; and Te Kahui Rongoa Trust "Submission to the Ministry of Business, Innovation and Employment on the disclosure of origin of genetic resources and traditional knowledge in the patents regime: discussion paper".

133 Castalia Strategic Advisors, above n 131, at iii.

134 MBIE, above $\mathrm{n} 1$, at $18-19$.

135 At $18-19$.

136 At 19-20. 
requirement would be more effective in ensuring better quality decision-making was undertaken by IPONZ when granting patents, this was viewed to have little additional impact on decisions relating to Māori compared to the medium requirement due to existing regulatory arrangements in New Zealand. ${ }^{137}$

Without bioprospecting and ABS regimes, patent applicants would have no obligation to provide evidence of such arrangements with iwi and hapū. MBIE also mentioned that international discussions on disclosure of origin coloured their assessment. ${ }^{138}$ MBIE's view was that New Zealand could benefit from large economies implementing a disclosure of origin requirement, and specifically mentioned the United States. ${ }^{139}$ Given the strength of the United States' opposition to a disclosure of origin requirement, ${ }^{140}$ this seems unlikely, which may have been an influencing factor. Ultimately, because the medium requirement would not result in as many administrative and compliance costs as the strong requirement, the reduction in information was justifiable. ${ }^{141}$

\section{B The Waitangi Tribunal's Approach}

The Wai 262 claim was lodged with the Waitangi Tribunal in 1991 by six claimants. ${ }^{142}$ The claim involved questions around who controlled mātauranga Māori, and the place that kaitiaki obligations towards taonga should have in contemporary New Zealand. ${ }^{143}$ In contrast to previous Waitangi Tribunal claims, Wai 262 focussed on contemporary issues rather than historical grievances, and was the first whole of government inquiry undertaken by the Tribunal. ${ }^{144}$ The Waitangi Tribunal released its report on 2 July 2011, 20 years after the claim was lodged. ${ }^{145}$

In the Wai 262 report, Ko Aotearoa Tēnei, the Waitangi Tribunal recommended a suite of reforms intended to make existing systems in New Zealand Treaty-compliant. ${ }^{146}$ These included introducing

137 At $19-20$.

138 At $19-20$.

139 At 20.

140 Kuruk, above n 39, at 45-46; and WTO The relationship between the TRIPS Agreement and The Convention on Biological Diversity, above n 6, at 4 and 14-22.

141 MBIE, above n 1, at 19-20.

142 Waitangi Tribunal "Ko Aotearoa Tēnei: Report on the Wai262 claim released" <www.waitangitribunal.govt.nz/news>.

143 Waitangi Tribunal, above n 142.

144 Waitangi Tribunal, above n 142.

145 Waitangi Tribunal, above n 142.

146 Ko Aotearoa Tènei: Te Taumata Tuarua vol 1, above n 3, at 198. 
a bioprospecting regime, and reforming areas of New Zealand's intellectual property regime, including: $:^{147}$

(a) Establishing a PMAC that is competent to advise on both patentability criteria and on whether kaitiaki interests could be at risk, even if patentability criteria is satisfied, and even when the Commissioner does not directly refer an application.

(b) Ensuring that the Commissioner of Patents is explicitly permitted to refuse a patent if it would be inconsistent with protecting kaitiaki relationships under the ordre public exception.

(c) Giving hapū and iwi the option to register kaitiaki interests in taonga resources and mātauranga to ensure such interests can be considered as a matter of course and at an early stage.

(d) Requiring patent applicants to disclose taonga species and mātauranga used in their inventions.

The Waitangi Tribunal recommended that a disclosure requirement was necessary in New Zealand to trigger early engagement with kaitiaki interests in the patent process. ${ }^{148}$ This would ensure that kaitiaki interests and other legitimate interests (such as those of the applicant) were considered and balanced before a patent was granted. Relying on opposition and revocation processes places the burden on kaitiaki to actively challenge the grant, which could be timely and expensive, deterring kaitiaki from making those challenges. ${ }^{149}$ The disclosure requirement proposed by the Waitangi Tribunal would require patent applicants to disclose: ${ }^{150}$

(a) the source and country of origin of any genetic or biological resources that contributed in any material way to the invention; and

(b) mātauranga Māori used in the course of research, including where the knowledge was not integral to the research, but prompted the course of research.

In contrast, the options discussed by MBIE made no distinction between disclosure for use of genetic resources compared to mātauranga. Under all three of MBIE's options, applicants would be required to make a disclosure if genetic resources or traditional knowledge were used in the invention. ${ }^{151}$ For disclosure of genetic resources, MBIE considered "used" as meaning the invention was directly based on the genetic resources. For disclosure of traditional knowledge, MBIE considered that "used" should mean the inventor knew of the traditional knowledge and used it to develop their

147 Ko Aotearoa Tēnei, above n 3, at 89-94.

148 Ko Aotearoa Tēnei: Te Taumata Tuarua vol 1, above n 3, at 203-204.

149 At 203-204. See generally WTO The relationship between the TRIPS Agreement and The Convention on Biological Diversity, above n 6.

150 Ko Aotearoa Tēnei: Te Taumata Tuarua vol 1, above n 3, at 204.

151 MBIE, above $\mathrm{n}$, at 13-14. 
invention. ${ }^{152}$ This reads more narrowly than the Waitangi Tribunal's formulation of "used in the course of research, including where the knowledge that is not integral ... but ... prompted the ... course of research". ${ }^{153}$ Consider the following illustration: rosy periwinkle was used by traditional Madagascaran healers to treat diabetes. ${ }^{154}$ The plant was accessed by researchers seeking an alternative to injectable insulin. ${ }^{155}$ Further research was undertaken, at significant time and expense, and it was discovered that the plant had compounds that could be used to treat cancer. ${ }^{156} \mathrm{~A}$ large pharmaceutical company patented the medication and profited significantly. ${ }^{157}$ At this point, it can be said that indigenous use of the plant as a medication prompted the course of research - its uses would not be known and this research not undertaken without it. ${ }^{158}$ Yet that knowledge did not contribute to developing the cancer medication - only the diabetes medication. ${ }^{159}$ Under MBIE's formulation, the applicant would not be required to disclose use of this knowledge.

The Commissioner of Patents would have discretion as to consequences for non-compliance. ${ }^{160}$ The Waitangi Tribunal envisaged that in some cases, no consequences would be necessary because the kaitiaki interest would not be harmed, or harm could be mitigated. ${ }^{161}$ In others, revocation or refusal of the patent may be justified because damage to the kaitiaki relationship would be extremely detrimental. ${ }^{162}$ As opposed to choosing either a formal or substantive requirement, as was the approach taken in MBIE's discussion paper, this disclosure requirement utilises both. Any decision made by the Commissioner would require a balancing of interests - of the kaitiaki interest; the applicant's interest; and the interests of wider society more generally - on a case by case basis. ${ }^{163}$ The Waitangi Tribunal preferred this to purely substantive or formal consequences because it provides an incentive for patent applicants to comply with disclosure, but avoided concerns that patents could be

152 At 23.

153 Ko Aotearoa Tēnei: Te Taumata Tuarua vol 1, above n 3, at 204.

154 Kuruk, above n 39, at 1.

155 At 1.

156 At 1.

157 At 1

158 This point was made generally in New Zealand Law Society "Submission to the Ministry of Business, Innovation and Employment on the disclosure of origin of genetic resources and traditional knowledge in the patents regime: discussion paper".

159 This point was made generally in New Zealand Law Society, above n 158.

160 Ko Aotearoa Tēnei: Te Taumata Tuarua vol 1, above n 3, at 205.

161 At 205.

162 At 205.

163 At 205. 
revoked or refused in "draconian" cases of mistake or error, and where no damage to the kaitiaki relationship would occur. ${ }^{164}$

\section{DESIGNING A DISCLOSURE OF ORIGIN REQUIREMENT}

The disclosure of origin requirement sparks an interesting debate in many respects: what should a patent applicant be required to disclose? What should an applicant do if they do not know the origin of traditional knowledge or genetic resources utilised in their invention? What should the penalty or sanction be for non-compliance? In its discussion paper, MBIE sought specific feedback on the design of the disclosure requirement, particularly on the subject matter for disclosure; trigger for disclosure; and consequences for non-compliance. This Part will examine the different options within each design element and evaluate the benefits and disadvantages, drawing on the options suggested by MBIE, the Waitangi Tribunal in Ko Aotearoa Ténei and discussed by the WTO and WIPO. ${ }^{165}$

\section{A Subject Matter}

Debates in the international forum on the subject matter for disclosure are centred on the definition of genetic resources and traditional knowledge. Part of the argument, raised by the United States, is that patent applicants should only be required to disclose genetic resources or traditional knowledge that are necessary in order for a person skilled in the art to be able to replicate the invention - in other words, relevant to patentability. ${ }^{166}$ Implementing a disclosure of origin requirement in an international treaty would do little to contribute to patentability, and would only "open up an avenue of litigation", creating a "cloud of uncertainty". ${ }^{167}$ Disclosure of origin could lead to increased litigation. One could question whether this is a bad thing. In most patent systems, third parties can oppose a patent or apply for re-examination post-grant. ${ }^{168}$ This involves litigation and can result in a revocation. However, it is a reactive measure rather than a preventive one. ${ }^{169}$ It requires indigenous groups such as Māori to initiate proceedings, which is burdensome and expensive. ${ }^{170}$ The disclosure requirement does not

164 At 205.

165 This is most specifically discussed in IGC WIPO Technical Study, above n 7, and WTO The relationship between the TRIPS Agreement and The Convention on Biological Diversity, above $\mathrm{n} 6$.

166 Kuruk, above n 39, at 45-46.

167 Joshua D Sarnoff and Carlos M Correa Analysis of Options for Implementing Disclosure of Origin Requirements in Intellectual Property Applications: A contribution to UNCTAD's response to the invitation of the Seventh Conference of the Parties of the Convention on Biological Diversity UNCTAD/DITC/TED/2005/14 (2006) at 7; and Kuruk, above n 39, at 45-46.

168 Lai, above n 75, at 40; and WTO The relationship between the TRIPS Agreement and The Convention on Biological Diversity, above n 6, at 12.

169 WTO The relationship between the TRIPS Agreement and The Convention on Biological Diversity, above $\mathrm{n}$ 6 , at 12 .

170 At 12 . 
increase litigation, but moves from a reactive measure to a preventive one. This aims to reduce the grant of bad patents rather than allowing them to be granted unnoticed. It may also lead to greater certainty, rather than uncertainty, by reducing the chances of later opposition or re-examination of patents. ${ }^{171}$

The Waitangi Tribunal defined the subject matter as "any genetic or biological resource". ${ }^{172}$ The CBD defines biological resources as "genetic resources, organisms or parts thereof, populations or any biotic component of ecosystems with actual or potential use or value for humanity". ${ }^{173}$ This seems somewhat circular, and may not assist applicants in determining the information they should disclose. One of the key functions of a disclosure requirement is to ensure that IPONZ has all the relevant information before it in order to consider patentability and identify when to refer to the PMAC including information provided to challenge or oppose applications. ${ }^{174}$ Consequently, a broad and straightforward definition, such as the one suggested by the Waitangi Tribunal, is preferred.

Aside from definition, there are other issues, such as whether derivatives of genetic resources (such as plant resin as opposed to the plant; or snake venom as opposed to the snake) and genetic sequence data (also known as digital DNA) should be included in the subject matter of disclosure. ${ }^{175}$ Derivatives are included under the Nagoya Protocol, but not the CBD. ${ }^{176}$ The distinction is in whether the resource has a functional unit of hereditary (ie genes/DNA) - if it does not, it is a derivative. These definitions are focussed on scientific terminology. One may question whether the distinction between derivatives and functional units of hereditary is a useful one when the issue for Māori is the kaitiaki relationship. Use of a derivative may pose less risk to the kaitiaki relationship, but it may, in some circumstances, still damage it. It is better to include this within the scope, but to specify that a derivative was utilised.

MBIE also proposed the following definition of traditional knowledge from Ko Aoteoroa Tēnei: ${ }^{177}$

171 Lai, above n 75, at 40; and Sarnoff and Correa, above n 167, at 7.

172 Ko Aotearoa Tēnei: Te Taumata Tuarua vol 1, above n 3, at 204 and 210.

$173 \mathrm{CBD}$, above $\mathrm{n}$ 9, art 2, as quoted in MBIE, above n 1, at 21.

174 At 5 .

175 At $21-22$.

176 MBIE, above n 1, at 21. See CBD, above n 9, art 2 definition of "genetic material" and "biological material". See also Nagoya Protocol on Access to Genetic Resources and the Fair and Equitable Sharing of Benefits Arising from their Utilization to the Convention on Biological Diversity UNEP/CBD/COP/DEC/X/1 (opened for signature 2 February 2011, entered into force 12 October 2014) [Nagoya Protocol], art 2 definition of "derivatives".

177 Ko Aotearoa Tènei: Te Taumata Tuarua vol 1, above n 3, at 204, as quoted in MBIE, above n 1, at 22. 
... the content or substance of knowledge resulting from intellectual activity in a traditional context, and includes the know-how, skills, innovations, practices and learning that form part of traditional knowledge systems, and knowledge embodying traditional lifestyles of indigenous and local communities, or contained in codified knowledge systems passed between generations. It is not limited to any specific technical field, and may include agricultural, environmental and medicinal knowledge, and knowledge associated with genetic resources.

There are ongoing debates about the appropriate definition of traditional knowledge, including those who argue that including a definition unnecessarily limits the scope of indigenous knowledge that triggers disclosure requirements, ${ }^{178}$ or does not truly reflect the way indigenous knowledge is developed. ${ }^{179}$ A statutory definition would need to be clear enough to ensure that the information to be disclosed is legally certain for patent. ${ }^{180}$ This may result in a definition being drafted too narrowly, or being applied too strictly - consequently leading to relevant information not being disclosed to IPONZ. A better approach would be to leave traditional knowledge and mātauranga Māori undefined in legislation, and to include broad definitions and examples in the IPONZ guidelines. ${ }^{181}$ In this way, both clarity and certainty can be achieved, while avoiding the risk of excluding relevant aspects of mātauranga Māori from disclosure.

\section{B Trigger for Disclosure}

Multiple different triggers for disclosure have been discussed, both in New Zealand and in international forums. Whether an applicant is required to disclose genetic resources or traditional knowledge accessed in the course of their research depends on the relationship between the resource and the invention. ${ }^{182}$

The Nagoya Protocol (to which New Zealand is not a party) for example defines "utilisation of genetic resources" as being to "conduct research and development on the genetic and/or biochemical composition of genetic resources, including through the application of biotechnology as defined in

178 Frankel and Lai, above n 31, at 31 .

179 At 31; and World Intellectual Property Organization Intellectual Property and Genetic Resources, Traditional Knowledge and Traditional Cultural Expressions (2015) at 13-14. See generally Le Gall, above n 27.

180 New Zealand Institute of Patent Attorneys "Submission to the Ministry of Business, Innovation and Employment on the disclosure of origin of genetic resources and traditional knowledge in the patents regime discussion paper".

181 The benefit of broad definition was discussed generally in Aman Gebru "Patents, Disclosure and Biopiracy" (2019) 96 Denver Law Review 535.

182 MBIE, above n 1, at 22. 
Article 2 of the Convention". ${ }^{183}$ The triggers for disclosure being considered in the WIPO Intergovernmental Committee on Intellectual Property and Genetic Resources, Traditional Knowledge and Folklore (WIPO-IGC) draft articles $^{184}$ are where the subject matter of a patent includes "utilisation of", or "is directly based on", genetic resources or traditional knowledge based on genetic resources. ${ }^{185}$ "Utilisation" was defined broadly in line with the Nagoya Protocol. ${ }^{186}$ An invention "directly based on" genetic resources or associated traditional knowledge would be one making immediate use of the resource and depend on the resource's specific properties, to which the inventor must have had physical access. ${ }^{187}$ However, inventions may be "derived from" genetic resources or the associated traditional knowledge in other ways, such as where the resource facilitated the invention (for example, making it easier to develop or conceive the invention) but is not necessary in the invention. ${ }^{188}$

In its discussion paper, MBIE noted that the same triggers can be used for traditional knowledge based on genetic resources. ${ }^{189}$ Because of the intangible nature of traditional knowledge, the inventor must have consciously derived their invention from the knowledge. ${ }^{190}$ MBIE considered that the Waitangi Tribunal approach was in line with the "utilisation" or "derived on" triggers. ${ }^{191}$ As discussed previously, this does not accurately capture the breadth of the approach suggested by the Tribunal, which specifically included anything that "contributed to the research or invention in any way". ${ }^{192}$ MBIE sought feedback on the appropriate triggers for both, and on whether the triggers for disclosure should be aligned. ${ }^{193}$

183 Nagoya Protocol, above n 176, art 2(c). "Biotechnology" is defined in CBD, above n 9, art 2 to mean "any technological application that uses biological systems, living organisms, or derivatives thereof, to make or modify products or processes for specific use".

184 IGC Draft Articles, above n 7.

185 At 10.

186 At 7.

187 At 6 . See also the disclosure requirement proposed by Switzerland, which also uses the "directly based on" trigger, as discussed in Girsberger, above n 122, at 474-475.

188 IGC WIPO Technical Study, above n 7, at 36-37.

189 MBIE, above $\mathrm{n} 1$, at 23.

190 At 23. See also Girsberger, above n 122, at 474-475.

191 MBIE, above $\mathrm{n} 1$, at 23.

192 Ko Aotearoa Tēnei: Te Taumata Tuatahi, above n 3, at 97.

193 MBIE, above n 132, at 23. 
Submitters on MBIE's discussion paper from the legal sector preferred the trigger for disclosure of genetic resources to be limited to inventions that directly use the resource. ${ }^{194}$ An applicant would typically only be required to disclose genetic resources that contributed to the process of invention or are necessary in order for a person skilled in the art to replicate the invention (ie relevant to patentability criteria). ${ }^{195}$ Having a trigger such as "utilised" or "derived from" may make it difficult for inventors to identify whether they have a duty to disclose anything; the higher threshold of "directly based on" means that a patent applicant would be able to easily verify whether they are required to disclose any genetic resources by checking which resources had been physically accessed. ${ }^{196}$ Any risk of uncertainty, however, is mitigated by allowing the applicant to declare the source of a genetic resource (ie the gene bank it was sourced from), as suggested in the medium disclosure requirement by MBIE. ${ }^{197}$ Requiring a high threshold such as physical access to the genetic resource may mean that taonga resources accessed through secondary means such as gene banks are not disclosed, despite their use having the potential to affect detrimentally the kaitiaki relationship with that resource. ${ }^{198}$ In order to ensure that relevant applications are referred to the PMAC for consideration, either the "utilisation" or "derivation" triggers would be preferable. In saying that, if genetic resources are used indirectly and have not contributed to the process or final invention, the relationship between the invention and genetic resource is weak, and there is consequently little risk of damage to the kaitiaki relationship in commercialising that invention.

Submitters believed that the trigger for disclosure of traditional knowledge should be broad enough to include any use of mātauranga - including in research. ${ }^{199}$ In general, traditional knowledge associated with genetic resources can be useful for researchers by providing information on different uses of plant species, pointing out areas for potential research. ${ }^{200}$ It often forms the background to the invention. ${ }^{201}$ Consequently, traditional knowledge is frequently utilised within a research process, but

194 At 6 .

195 IGC WIPO Technical Study, above n 7, at 36; and Gebru, above n 181, at 579-580.

196 MBIE, above n 132, at 6.

197 MBIE, above n 1; and Gebru, above n 181, at 579-580

198 For discussion on the importance of disclosure for the kaitiaki obligation see Ko Aotearoa Tènei: Te Taumata Tuatahi, above n 3, at 88-89.

199 MBIE, above n 132, at 6; Te Hunga Rōia Maori o Aotearoa "Submission to the Ministry of Business, Innovation and Employment on the disclosure of origin of genetic resources and traditional knowledge in the patents regime: discussion paper"; Te Rūnanga o Ngāi Tahu "Submission to the Ministry of Business, Innovation and Employment on the disclosure of origin of genetic resources and traditional knowledge in the patents regime: discussion paper"; and New Zealand Institute of Patent Attorneys, above n 180.

200 Ko Aotearoa Ténei: Te Taumata Tuatahi, above n 3, at 72.

201 IGC WIPO Technical Study, above n 7, at 37. 
the final product may not be "directly based on" or "utilise" that knowledge. ${ }^{202}$ If one of these were used as the trigger for disclosure, as opposed to "derivation", inventions that used mātauranga Māori in this way would not be disclosed. ${ }^{203}$ Relevant iwi and/or hapū would have no way of identifying, challenging and opposing uses of mātauranga until after the patent was granted. Consequently, there may be no reason for IPONZ to refer the application to the PMAC for consideration, and relevant kaitiaki relationships may be overlooked. This justifies a lower trigger for disclosure of traditional knowledge, then, which should align with the suggestion made by the Waitangi Tribunal, and broadly in line with "derivation". Because disclosure of traditional knowledge requires some aspect of conscious exploitation, patent applicants need not be concerned that they could accidentally fail to disclose their use of genetic resources or traditional knowledge. However, this also means it could be relatively easy for applicants to circumvent a disclosure obligation by denying conscious knowledge of the resources utilised - particularly for traditional knowledge.

\section{Consequences for Non-compliance}

As mentioned above, patent applicants may circumvent the requirement by intentionally neglecting to disclose the resources used in their invention, or by lying about them. ${ }^{204}$ Equally, applicants may overlook or forget to disclose the resources used. ${ }^{205}$ A substantive disclosure requirement would have sanctions within the patent regime. In effect, this would make disclosure of origin a prerequisite for patentability. ${ }^{206}$ If non-compliance was detected under a formal disclosure requirement like the basic or medium requirements, a patent application would not proceed until the relevant information was provided. ${ }^{207}$ Some have suggested that sanctions should be available within civil or administrative law for deliberate non-compliance, such as an order to pay a fine or compensation. ${ }^{208}$

202 Ko Aotearoa Tènei: Te Taumata Tuatahi, above n 3, at 88.

203 At 88-93; and New Zealand Institute of Patent Attorneys, above n 180.

204 WTO The relationship between the TRIPS Agreement and The Convention on Biological Diversity, above $\mathrm{n}$ 6, at 48-50; and Margo A Bagley "'Ask Me No Questions': The Struggle for Disclosure of Cultural and Genetic Resource Utilization in Design" (2018) 20 Vand J Ent \& Tech L 975 at 1016.

205 Dawkins, above n 38, at 27; and New Zealand Institute of Patent Attorneys, above n 180.

206 IGC WIPO Technical Study, above n 7, at 50-53; Girsberger, above n 122, at 477; and MBIE, above n 1, at 14.

207 IGC WIPO Technical Study, above n 7, at 50-53; Girsberger, above n 122, at 476-478; and MBIE, above n 1 , at $13-14$.

208 IGC WIPO Technical Study, above n 7, at 50-53; Girsberger, above n 122, at 476-478; and MBIE, above n 1 , at $13-14$. 
Having sanctions outside the patent system arguably reduces any effect or impact the disclosure requirement could have. ${ }^{209}$ The power of the patent system lies in its ability to grant or deny exclusive monopoly control over the commercialisation of an invention. ${ }^{210}$ This confers a distinct competitive advantage on the patent holder which should not be awarded if the invention relied on misappropriation. ${ }^{211}$ The disclosure requirement would be ineffective at protecting indigenous groups from misappropriation if patents were still awarded, and the patent holder only required to pay a fine or compensation. ${ }^{212}$ Under this approach, applicants may choose to circumvent the disclosure requirement by stating they are unaware of the origin of resources or knowledge used, or by simply failing to disclose their use at all. ${ }^{213}$ Fines or compensation, in effect, allow companies and researchers to pay for the privilege of misappropriation. ${ }^{214}$ If applicants are aware that their patent may be revoked or refused on this ground, they are more likely to comply - especially because the threat of revocation applies throughout the term of the patent. ${ }^{215}$ The potential for a patent to be refused or revoked is a stronger incentive than administrative or civil sanctions. ${ }^{216}$

Conversely, revocation or refusal of a patent may have unjustified adverse effects on patent applicants. In cases where the applicant has acted in good faith, or where the impacts of noncompliance are minor, substantive sanctions may be overly harsh. ${ }^{217}$ The Waitangi Tribunal expressed this concern in Ko Aotearoa Tēnei: ${ }^{218}$

Uniformly harsh consequences that affect the validity of a patent even when the effect on the kaitiaki relationship is minimal would have an unnecessarily chilling impact on research and development and on the biotechnology sector, and cannot be justified.

209 Graeme Laurie "Should There Be an Obligation of Disclosure of Origin of Genetic Resources in Patent Applications - Learning Lessons from Developing Countries" (2005) 2 SCRIPT-ed 265 at 270.

210 Laurie, above n 209, at 270; and Brendan M Tobin "Bridging the Nagoya Compliance Gap: The Fundamental Role of Customary Law in Protection of Indigenous Peoples' Resource and Knowledge Rights" (2013) 9 Law, Environment and Development Journal 142 at 150.

211 Frankel, above n 23, at 86-87; and Sarnoff and Correa, above n 167, at 5.

212 Laurie, above n 209, at 270.

213 IGC WIPO Technical Study, above n 7, at 26-27.

214 For a discussion on fines and compensation see IGC WIPO Technical Study, above n 7, at 50-53.

215 Ko Aotearoa Tēnei: Te Taumata Tuarua vol 1, above n 3, at 225.

216 Bagley, above n 204, at 1016.

217 IGC WIPO Technical Study, above n 7, at 50-53.

218 Ko Aotearoa Tēnei: Te Taumata Tuatahi, above n 3, at 93. 
While strongly incentivising compliance, substantive sanctions may deter research and development, or use of the patent system as a method of commercialisation. ${ }^{219}$ As MBIE noted, this would reduce the information IPONZ could gather on the use of taonga species and mâtauranga Māori, and the effectiveness of a disclosure of origin in enabling iwi and hapu to protect their kaitiaki relationships. ${ }^{220}$

The WIPO-IGC, in discussing this issue, looked more broadly to other disclosures required in patent regimes (such as disclosure related to novelty and prior art). In doing so, it noted that the consequences for failing to meet these disclosure requirements varied considerably: if disclosure is inadequate and does not include important and relevant information, a patent may be rejected or invalidated. ${ }^{221}$ If a person other than the true inventor applies for the patent, patent rights may be revoked or transferred. ${ }^{222}$ If administrative information is omitted, that information can often be corrected or remedied. ${ }^{223}$ The consequences for failure to disclose vary based on whether the failure was due to fraud or mistake and whether the information that should have been disclosed is of a nature that may affect a patent examiner's ability to assess patentability. ${ }^{224}$ The Waitangi Tribunal recommended having both formal and substantive sanctions available for non-compliance. ${ }^{225}$ This was in part to balance the need to incentivise compliance with the disclosure requirement, which a purely formal requirement may be unable to achieve, with the need to encourage genuine innovation and research. ${ }^{226}$ It was also in part due to the focus of the Waitangi Tribunal's recommendations in protecting kaitiaki relationships. $^{227}$

219 Dawkins, above n 38, at 27.

220 MBIE, above $\mathrm{n} 1$, at $15-16$.

221 IGC WIPO Technical Study, above n 7, at 26.

222 At 26.

223 At 26.

224 At 26.

225 Ko Aotearoa Tènei: Te Taumata Tuatahi, above n 3, at 93.

226 At 93 .

227 See the discussion on kaitiaki concerns in Ko Aotearoa Tēnei: Te Taumata Tuatahi, above n 3, at 17-23. 
If patents could be refused or revoked on the basis of its impact on the kaitiaki relationship, the patent system itself may become more uncertain. ${ }^{228}$ The Waitangi Tribunal acknowledged this in Ko Aotearoa Tēnei: 229

Naturally, this approach comes with an element of uncertainty. There is, however, nothing new in it, since granted patents are exposed to the ongoing possibility of objection or revocation anyway. It is also consistent with the highly discretionary approach we favour in other parts of this and the previous chapter.

Revoking or refusing a patent on the grounds of a kaitiaki relationship could be seen as a deviation from patentability criteria. ${ }^{230}$ Applicants may be unable to predict the likelihood of their patent being granted. ${ }^{231}$ Equally, however, this may motivate and incentivise researchers to proactively engage with and consult iwi and hapū about their use of taonga species and mātauranga Māori to avoid using them in a way that could damage the kaitiaki relationship, or to establish methods of commercialisation that could mitigate or reduce damage. ${ }^{232}$

It would make little sense to revoke or refuse a patent for failing to disclose the use of taonga species or mātauranga Māori if, in fact, the use and commercialisation of the invention would have no impact on kaitiaki interests. If the kaitiaki relationship, however, would be detrimentally impacted to a severe degree and there was no available mechanism to refuse or revoke the patent, iwi and hapū would be unable to protect their interests. This would leave the system in the same position it had been in prior to implementing a disclosure requirement, albeit with slightly better mechanisms for IPONZ to determine which applications to refer to the PMAC - assuming applicants complied with the requirement. Without some potential to utilise substantive sanctions, disclosure of origin would be reduced to a tokenistic appearance of including Māori interests in the intellectual property system without allowing those interests to have any real role or contribution. For meaningful interaction with iwi and hapū, there must be a mechanism for those contributions to have an impact on the system.

228 New Zealand Institute of Patent Attorneys, above n 180; Hoare and Tarasofsky, above n 55, at 154-155; WTO The relationship between the TRIPS Agreement and The Convention on Biological Diversity, above n 6, at 48-50; and MBIE, above n 1, at 9.

229 Ko Aotearoa Tēnei: Te Taumata Tuarua vol 1, above n 3, at 205.

230 WTO The relationship between the TRIPS Agreement and The Convention on Biological Diversity, above $\mathrm{n}$ 6 , at 60 .

231 New Zealand Institute of Patent Attorneys, above n 180; Hoare and Tarasofsky, above n 55, at 154-155; WTO The relationship between the TRIPS Agreement and The Convention on Biological Diversity, above n 6, at 48-50; and MBIE, above $n$ 1, at 9.

232 Ko Aotearoa Tēnei: Te Taumata Tuarua vol 1, above n 3, at 203-205. 


\section{GENERAL CONCERNS ABOUT IMPLEMENTING A DSCLOSURE OF ORIGIN REQUIREMENT}

In addition to debates around design of a disclosure requirement, there are further concerns with implementing a disclosure requirement that have been discussed by MBIE and the Waitangi Tribunal. Firstly, it may increase the burden placed on IPONZ, both financially and in the resources required to assess applications. ${ }^{233}$ Secondly, it may increase the burden placed on patent applicants. ${ }^{234}$ This Part will consider the extent to which these concerns are valid, and if so, whether they can be mitigated.

\section{A Increased Burden on Patent Examiners}

One of the reasons MBIE preferred a medium mandatory disclosure requirement was because it balanced the need for quality information collection with the potential for increased compliance and administrative costs at IPONZ. ${ }^{235}$ IPONZ would be required to notify patent applicants and other interested groups of the changes; train their employees; and create mechanisms for internal guidance. ${ }^{236}$ IPONZ would also face increased administrative and compliance costs in the time taken to process patent applications. ${ }^{237}$ In an economic assessment, the direct costs across a 30 year period would be between $\$ 772,000$ for the basic requirement to $\$ 4,556,000$ for the strong requirement, ${ }^{238}$ or between $\$ 1.4$ and $\$ 7.5$ million overall. ${ }^{239}$ It should be noted that, overall, patent applications have decreased by 28 per cent since 2006 and decrease on average by two per cent each year. ${ }^{240}$ In the economic report, Castalia Strategic Advisors also assessed the increased costs to IPONZ being low in all three scenarios. ${ }^{241}$ The risk of a significant financial burden being placed on IPONZ as a result of the disclosure requirement is therefore relatively low.

Concerns raised in the international forum were also that a disclosure requirement would create difficulties for patent offices verifying the truthfulness and accuracy of disclosures made. ${ }^{242}$ Many patent examiners would be ill-equipped to identify applications where genetic resources or traditional

233 See generally MBIE, above $\mathrm{n} 1$.

234 See generally MBIE, above $\mathrm{n} 1$.

235 At vii.

236 Castalia Strategic Advisors, above n 131, at iv.

237 At iv.

238 MBIE, above n 1, at 16-17. See also Castalia Strategic Advisors, above n 131.

239 Castalia Strategic Advisors, above n 131, at v-vi.

240 At 7.

241 At iv.

242 WTO The relationship between the TRIPS Agreement and The Convention on Biological Diversity, above n 6 , at 61 . 
knowledge should have been disclosed. ${ }^{243}$ Once disclosed, patent offices may need to seek further information on the content of that resource or knowledge in order to assess whether it is patentable. ${ }^{244}$ The patent system could become overloaded, resulting in lengthy delays and significant burden and pressure being placed on examiners. ${ }^{245}$ However, this is unlikely to be an issue. The disclosure of genetic resources and traditional knowledge can serve as a notification to interested third parties of the application. ${ }^{246}$ Those parties would be able to oppose the patent and provide evidence that the invention does not meet patentability criteria. ${ }^{247}$ IPONZ would not necessarily be obligated to actively investigate unless there was some concern about patentability. ${ }^{248}$ IPONZ's role would be to assess patent applications as it does already, and to refer relevant applications to the PMAC. It is for the PMAC to engage in a deeper consideration of iwi and hapu interests - a role the committee already has under the Patents Act.

\section{B Increased Burden on Patent Applicants}

MBIE considered that some disclosure requirements would require significant extra effort from patent applicants. ${ }^{249}$ Both the basic and medium requirements allow for an applicant to declare that they are unaware of the origin. ${ }^{250}$ The medium disclosure instead requires the applicant to disclose the source of the genetic resources or traditional knowledge. ${ }^{251}$ While this reduces some of the burden, it still requires the applicant to be able to identify whether relevant resources or knowledge were used in the invention. Because patents are often applied for many years after resources were accessed, this may be "practically impossible" without significant effort. ${ }^{252}$ This is viewed by some as disproportionate to the problem of misappropriation. ${ }^{253}$ Part of this issue is related to design. Are patent applicants expected to go beyond the information that is readily available to them in order to actively trace the origins of genetic resources and traditional knowledge used in their invention and

243 Ko Aotearoa Tēnei: Te Taumata Tuatahi, above n 3, at 91; Girsberger, above n 122, at 483-484; and Frankel and Lai, above n 31, at 119.

244 Hoare and Tarasofsky, above n 55, at 150.

245 At 150 .

246 MBIE, above n 1, at 11; and Kuruk, above n 39, at 63.

247 MBIE, above n 1, at 11; and Kuruk, above n 39, at 63.

248 See MBIE, above n 1 , at 13 and 24.

249 At $15-16$.

250 At $13-14$

251 At 14 .

252 New Zealand Institute of Patent Attorneys, above n 180; and MBIE, above n 132, at 3.

253 Hoare and Tarasofsky, above n 55, at 150. 
research? ${ }^{254}$ For the most part, this concern is not valid. The majority of inventors will (or should) at least know the source of any genetic resources or traditional knowledge used in their inventions and be able to disclose that. ${ }^{255}$ To ensure researchers and inventors are aware of patent requirements, IPONZ can educate applicants and create resources. ${ }^{256}$ This is likely sufficient to mitigate the risk of uncertainty.

The patent specification process imposes a burden on the applicant already. After all they will receive property rights and so need to establish that such rights are merited. Due to the complexity of the process, IPONZ recommends that applicants hire a patent attorney. ${ }^{257}$ It seems unlikely that a disclosure requirement would introduce any additional burden to applicants that could not adequately be managed by IPONZ or patent attorneys. As patents can have commercial benefit, it seems unlikely that inventors would be deterred from applying for them only as a result of IPONZ requiring more information from applicants than they currently do.

\section{REQUIRING DISCLOSURE OF ACCESS AND BENEFIT- SHARING (ABS) ARRANGEMENTS}

In international fora, disclosure requirements are an example of one battle within a wider context of challenging the patent system because it does not adequately meet the needs of developing countries. ${ }^{258}$ Some developing countries have argued that, in addition to disclosure of origin, patent applicants should be obliged to provide evidence of access agreements based on prior informed consent and evidence of arrangements for equitable benefit-sharing. ${ }^{259}$ If an applicant failed to provide this evidence, the patent examiner would refuse to process the application further. ${ }^{260}$ The

254 IGC WIPO Technical Study, above n 7, at 5.

255 WTO The relationship between the TRIPS Agreement and The Convention on Biological Diversity, above $\mathrm{n}$ 6 , at $43-44$.

256 The benefit of education and definition is generally discussed in: Dawkins, above n 38, at 27; and Lai, above n 75 , at 40 .

257 Castalia Strategic Advisors, above n 131, at 5.

258 Hoare and Tarasofsky, above n 55, at 150.

259 IGC WIPO Technical Study, above n 7, at 1-7 and 40-44; and WTO The protection of traditional knowledge and folklore, above n 6, at [28]-[37]. See generally WTO The relationship between the TRIPS Agreement and The Convention on Biological Diversity, above $\mathrm{n} 6$.

260 WTO The relationship between the TRIPS Agreement and The Convention on Biological Diversity, above $\mathrm{n}$ 6 , at 29. 
main argument in favour of such an approach is that it is more consistent with ABS obligations under the CBD. ${ }^{261}$

\section{A The Trend towards Indigenous Rights}

In the international forum, there has been a general trend towards increasing protection of indigenous rights. The Mataatua Declaration on Cultural and Intellectual Property Rights of Indigenous Peoples came into force in 1993, ${ }^{262}$ which affirmed the importance of indigenous peoples' knowledge and the need to protect it from exploitation. Specifically, the Mataatua Declaration provides that:

2.6 Indigenous flora and fauna is inextricably bound to the territories of indigenous communities and any property right claims must recognise their traditional guardianship.

2.7 Commercialization of any traditional plants and medicines of Indigenous Peoples, must be managed by the indigenous peoples who have inherited such knowledge.

Following that, the United Nations Declaration on the Rights of Indigenous Peoples (UNDRIP) was adopted by the United Nations in $2007 .{ }^{263}$ UNDRIP affirmed many rights of indigenous peoples, including the obligation of states to provide mechanisms to prevent disposition of indigenous peoples' lands, territories and resources (and provide redress for breaches); ${ }^{264}$ the right of indigenous peoples' to maintain and strengthen their spiritual relationship with traditionally owned lands and resources; ${ }^{265}$ and the right to own, use, develop and control their lands and resources, and receive legal recognition and protection for them. ${ }^{266}$

The demand for incorporating ABS requirements into the patent regime must be viewed within this context. Experiences of colonisation have meant that indigenous peoples' rights have frequently been neglected. ${ }^{267}$ The focus on the patent regime is part of a much broader issue with the intellectual property system as a whole, which has been used as a mechanism to misappropriate and exploit the

261 IGC WIPO Technical Study, above n 7, at 1 and 40-41; and WTO The protection of traditional knowledge and folklore, above n 6, at [28]-[37]. See generally WTO The relationship between the TRIPS Agreement and The Convention on Biological Diversity, above $\mathrm{n} 6$.

262 The Mataatua Declaration on Cultural and Intellectual Property Rights of Indigenous Peoples (June 1993).

263 United Nations Declaration on the Rights of Indigenous Peoples GA Res 61/295, A/RES/61/295 (2007) [UNDRIP].

264 Article 8(2).

265 Article 25.

266 Article 26.

267 Hoare and Tarasofsky, above n 55, at 159. 
knowledge and resources of indigenous peoples. ${ }^{268}$ Requiring proof of $\mathrm{ABS}$ arrangements is intended to ensure that patents are not granted in situations where the rights of indigenous peoples have not been observed - whether or not the invention meets patentability criteria. ${ }^{269}$ Patents should not be granted in such circumstances on the basis of social policy; the patent system should not reward inventors for inequitable or unethical behaviour. ${ }^{270}$

Some indigenous groups believe that patents should not be granted where the genetic resources or traditional knowledge of indigenous groups has been used without prior informed consent, or without benefit-sharing arrangements in place.

The obligations under the $\mathrm{CBD}$ are used to support this viewpoint. In counter, some members of the WTO argue that requirements such as ABS are not necessary or relevant to the patent system. ${ }^{271}$ The patent system is intended to incentivise innovation and economic development: if an invention is truly innovative, it should be protected. ${ }^{272}$ Consequently, patents should only be granted or rejected based on patentability criteria. ${ }^{273}$ An invention will not meet patentability criteria if it relies on the genetic resources or traditional knowledge of an indigenous group without any inventive step, or in a way that would be obvious to a person skilled in the art. ${ }^{274}$ This should prevent "bad patents" from being granted. ${ }^{275}$ If they are granted, indigenous peoples can oppose or challenge the patent postgrant. ${ }^{276}$ Concerns about compliance with ABS obligations are not specific to patent law. Frankel points out that ethical research practices are relevant to many fields. ${ }^{277}$ Patent law is intended to promote innovation by granting inventors exclusive commercial monopolies over their inventions. ${ }^{278}$ In order to obtain that right, inventors must disclose their inventions. ${ }^{279}$ This means others skilled in

268 See generally Le Gall, above n 27; Hoare and Tarasofsky, above n 55, at 159; and DS Fabricant and NR Farnsworth "The Value of Plants Used in Traditional Medicine for Drug Discovery" (2001) 109 Environ Health Persp 69, as cited in Frankel and Lai, above n 31, at 33.

269 Sarnoff and Correa, above n 167, at 5-6.

270 Frankel, above n 23, at 86-87; and Sarnoff and Correa, above n 167, at 5-6.

271 WTO The relationship between the TRIPS Agreement and The Convention on Biological Diversity, above $\mathrm{n}$ 6 , at $13-23$.

272 At $13-23$.

273 At 11 .

274 At 11.

275 At 11.

276 At 11.

277 Frankel, above n 23, at 86-87.

278 MBIE, above n 1, at 4.

279 See Patents Act, s 39(1)(a) and (b). 
the art can replicate the invention and innovate from it, benefitting society. ${ }^{280}$ This is known as the "patent bargain". Patents are intended to incentivise research and development, which involves a significant investment and may not otherwise occur. ${ }^{281}$ Financial investors, for example, may only fund research if they have the security of a patent. ${ }^{282}$ However, a patent is also a reward for socially beneficial behaviour (innovation). ${ }^{283}$ Patent law should not reward something that is contrary to social policy. ${ }^{284}$ Despite this, Frankel points out a patent confers right to exclude, not the right to use. ${ }^{285}$ The right to use an invention can be governed by other measures, such as specific legislation: it is not only the role of the patent system to ensure ethical research takes place. ${ }^{286}$ Despite this, there is an argument that the patent system should be conscious about what it rewards, ${ }^{287}$ and may be an "effective checkpoint" for unethical behaviour. ${ }^{288}$

\section{$B$ Problems with Requiring Evidence of ABS}

Disclosure of ABS arrangements could be either a formal or substantive requirement, as with disclosure of origin. In either instance, the same concerns arise as discussed above in the context of disclosure of origin.

It could be argued that considering ABS in general imposes a significant burden on IPONZ. When a patent applicant provides evidence of ABS, IPONZ would be required to check that these arrangements complied with the ABS regime in place in the relevant country of origin. ${ }^{289}$ This could result in delay, complication and significant administrative cost. If applicants were required to positively prove that access to the resources or benefit-sharing arrangements met a certain standard, an onerous additional burden could be placed on them. ${ }^{290}$ However, this burden could be displaced: once prima facie evidence of compliance has been provided (such as copies of contractual arrangements and licenses, or certificates and authorisation from competent authorities in the country

280 MBIE, above $\mathrm{n} 1$, at 4.

281 At 4.

282 Frankel, above n 23, at 87.

283 At $86-87$.

284 At 86-87; Sarnoff and Correa, above n 167, at 2-5; and Dawkins, above n 38, at 26.

285 Frankel, above n 23, at 86-87.

286 At $86-87$.

287 At $86-87$.

288 Dawkins, above n 38, at 26.

289 Laurie, above n 209, at 267-268; and Girsberger, above n 122, at 483-484.

290 IGC WIPO Technical Study, above n 7, at 5. 
of origin or source), it could be assumed that ABS obligations have been met. ${ }^{291}$ As with a disclosure of origin requirement, this would act as notification to states and indigenous groups with an interest in protecting their genetic resources; those third parties would be able to oppose the patent and prove otherwise. ${ }^{292}$ This would not necessarily impose any additional burden on IPONZ to actively verify the arrangements.

It could also be argued that this approach would impose a significant burden on the patent applicant, more so than disclosure of origin. In some situations, inventors may commence research and development, utilising genetic resources in the process, without realising that, should they eventually apply for a patent, evidence of an access arrangement will be required. ${ }^{293}$ This risk, however, could easily be mitigated through education or approval regimes. If a person accesses resources through secondary means, they may be unable to provide evidence of consent to access the resources. ${ }^{294}$ Even if the applicant provided evidence of the gene bank itself obtaining prior informed consent to utilise the resources from their origin, how far down the chain of usage would genetic resources need to be tracked ${ }^{295}$ Presumably, consent given by indigenous groups for one person or group to access and use them does not extend to all later uses. Is the patent applicant expected to trace the resources they used to investigate whether the circumstances of initial acquisition met access requirements? ${ }^{296}$ If so, this is an onerous burden and may introduce significant uncertainty to the patent regime and research process. ${ }^{297}$ It may deter beneficial research and development, or encourage inventors to utilise alternative methods of commercialisation. ${ }^{298}$ If not, then resources could be used without prior informed consent, which risks undermining the purpose of aligning the patent regime with CBD obligations.

\section{The Significance of the Treaty of Waitangi/Te Tiriti o Waitangi}

The relationship between the government and Māori is governed by the Treaty of Waitangi/Te Tiriti o Waitangi, which places New Zealand is a unique position. Article 2 of the English text of the

291 Dominic Keating "Access to Genetic Resources and Equitable Benefit Sharing Through a New Disclosure Requirement in the Patent System: An Issue in Search of a Forum" (2005) 87 J Pat \& Trademark Off Soc'y 525 at 539-540; and Hoare and Tarasofsky, above n 55, at 156.

292 Kuruk, above n 39, at 50; Keating, above n 291, at 539-540; and Hoare and Tarasofsky, above n 55, at 156.

293 IGC WIPO Technical Study, above n 7, at 2.

294 Laurie, above n 209, at 475; Dawkins, above n 38, at 27; and Girsberger, above n 122, at 34.

295 IGC WIPO Technical Study, above n 7, at 3.

296 At 5 .

297 IGC WIPO Technical Study, above n 7, at 2-5; and Hoare and Tarasofsky, above n 55, at 157.

298 Dawkins, above n 38, at 27. 
Treaty guarantees Māori the exclusive and undisturbed possession of their properties. ${ }^{299}$ In other words, the Crown guaranteed Māori protection over their property. Despite this, mātauranga Māori is not protected in New Zealand's intellectual property regime. This is partly because, as discussed earlier, western concepts of property do not neatly align with mātauranga Māori, which is not "possessed". ${ }^{300}$ In contrast, the Māori text of Te Tiriti guarantees Māori "te tino rangatiratanga ... o ratou taonga katoa" - full authority and control over all their treasured things. ${ }^{301}$ This version sits more comfortably with concepts of mātauranga and kaitiakitanga.

The disclosure of origin requirement is not simply about recognition or acknowledgement for the contributions Māori have made in research and invention. It is part of a much larger problem: that Māori in many respects are not afforded tino rangatiratanga. Some submitters who provided feedback to MBIE on their discussion paper indicated that MBIE had stated the issues too narrowly. ${ }^{302}$ The use of mātauranga Māori and taonga species relates directly to the dissonance between western and Māori conceptions of property and use, and more broadly to the imposition of a western legal system that does not recognise Māori interests. Some submitters consequently believed that a conversation about disclosure of origin could not occur in isolation from the other issues discussed by the Waitangi Tribunal in Ko Aotearoa Ténei. ${ }^{303}$ It is also interesting that in its report MBIE, Castalia Strategic Advisors listed consistency with the Treaty as one of the possible objectives of a disclosure of origin requirement, ${ }^{304}$ but MBIE did not include this as a stand alone objective in its discussion paper. ${ }^{305}$

\section{Recognising Māori in the Intellectual Property System}

The approaches taken by the Waitangi Tribunal and MBIE are at odds with one another. The Waitangi Tribunal's approach was to consider the interests of Māori, on Māori terms, and to find a way to engage with those interests within the intellectual property system. In contrast, MBIE's discussion was focused on ensuring IPONZ has information relevant to patentability; to help trigger referral to the PMAC for advice; and to gather information about the use of mātauranga Māori and taonga genetic resources in research. In other words, MBIE's paper is focused on the intellectual property system in western terms, and on the ways a disclosure requirement could lead to economic

299 Ko Aotearoa Tēnei: Te Taumata Tuatahi, above n 3, at 43.

300 At 43 .

301 At 43

302 MBIE, above n 132, at 1; New Zealand Institute of Patent Attorneys, above n 180; and University of Auckland Uniservices Ltd "Submission to the Ministry of Business, Innovation and Employment on the disclosure of origin of genetic resources and traditional knowledge in the patents regime: discussion paper".

303 New Zealand Institute of Patent Attorneys, above n 180; and Te Hunga Rōia Maori o Aotearoa, above n 199. This point was also raised in Girsberger, above $\mathrm{n}$ 127, at 480.

304 Castalia Strategic Advisors, above n 131, at iii.

305 This point was made in University of Auckland Uniservices Ltd, above n 302. 
benefit - it is not focused on the best method to engage with and involve and recognise te ao Māori in the intellectual property system on Māori terms. ${ }^{306}$ Simply disclosing the use of taonga species or mātauranga Māori is not enough. Kaitiaki have an interest in protecting and preserving their taonga. This could include ensuring taonga is used consistently with tikanga and is managed sustainably, and the importance of the kaitiaki interest will vary according to the relationships at stake. The requirements suggested by MBIE do not focus on the kaitiaki interest. The following sections of this paper will discuss the advantages and disadvantages of evidence of ABS and disclosure of origin in the patent regime in light of the kaitiaki interest highlighted by the Tribunal.

\section{Disclosing evidence of $A B S$}

While New Zealand is a party to the CBD, it is not party to the Nagoya Protocol, and does not have an access or benefit-sharing regime. Bioprospectors and researchers accessing genetic resources are not statutorily obliged to obtain prior informed consent from iwi and hapū or enter benefit-sharing arrangements. Even if an ABS regime was introduced, prior informed consent would be sought from a competent authority - not directly from iwi (though it is presumed that the authority would create mechanisms for consultation with Māori in relevant cases). Patent applicants in New Zealand would only be required to provide prior informed consent from the source country's competent authority. If the authority did not engage with the relevant indigenous group(s), this evidence would do little to protect the interests of indigenous peoples; only the Nagoya Protocol imposes obligations on states themselves to ensure that genetic resources and traditional knowledge are accessed with prior informed consent from indigenous groups. The CBD protects genetic resources; only the Nagoya Protocol specifically applies to traditional knowledge. Under the CBD, applicants have no obligation, even with a disclosure requirement, to provide evidence of $\mathrm{ABS}$ arrangements for traditional knowledge.

In the New Zealand context, many different iwi and hapu groups may whakapapa with certain taonga resources, or share similar knowledge. A patent applicant would likely need to provide evidence of ABS arrangements with each iwi and hapū who had a kaitiaki interest. It may be difficult for an inventor or researcher to identify each iwi or hapū group with a kaitiaki interest over a resource, as mātauranga Māori is often unwritten or secret. ${ }^{307}$ There is no database or resource that an inventor can access to check which iwi and hapū they may be required to seek prior informed consent from, or share benefits with. One concern is that this could make the patent system uncertain for patent applicants. If disclosure of ABS were a substantive requirement, the patent may be declined or revoked because prior informed consent was not sought from all relevant iwi and hapū, but the applicant may have had no way to know this. However, this may be a non-issue if applicants are able to seek benefit-sharing arrangements ex post. A further risk is that IPONZ, or even the PMAC, will

306 For a discussion on the need to focus on customary law and practice see Tobin, above n 210, at 150 .

307 Lai, above n 75 , at 38 . 
not have the expertise to identify all relevant iwi and hapu interests in a patent application. Prior informed consent from one iwi or hapū may be deemed sufficient to satisfy ABS arrangements, but there may be multiple groups who have a kaitiaki relationship with a particular resource. These are challenges that must be addressed if disclosure of evidence of ABS is intended to be introduced in the New Zealand patents regime: it may be extremely difficult to enforce an ABS regime without mechanisms in place to ensure IPONZ and patent applicants have relevant information at their disposal.

Finally, disclosure of ABS arrangements may not be useful in the patents regime. Requiring evidence of these arrangements appears to be aimed at seeking compliance with, in effect, ethical research practices. ${ }^{308}$ Not only is this an issue of policy, but one of effectiveness. In its technical study, the WIPO-IGC noted that the patent system may be unable to provide a comprehensive monitoring and compliance tool for all relevant uses of genetic resources under the CBD - likely because not all patents are relevant to the $\mathrm{CBD}$, and not all uses of genetic resources result in a patent application. ${ }^{309}$ There will be some instances where a patent relates to genetic resources covered by the CBD - but not all patents will do so. ${ }^{310}$ Firstly, an invention may utilise the genetic material of plants from another country, but that material may not be precious, valuable or regulated. ${ }^{311}$ Secondly, the source country may not have an ABS regime in place, in which case obligations under the CBD do not arise. ${ }^{312}$ Requiring disclosure of such obligations in every case increases the burden on both IPONZ and the patent applicant for little gain. Alternative arrangements may be just as effective, but less onerous. It may be sufficient to simply alert IPONZ by disclosing the genetic resources that have been used. IPONZ policy or procedure could be to require applicants to provide evidence of ABS arrangements, if disclosure of origin indicated that obligations under the CBD are relevant. ${ }^{313}$ An example of this policy approach can be seen in the IPONZ guidelines in 2008, which required applicants to provide evidence of prior informed consent if an invention related to taonga species or mātauranga Māori. ${ }^{314}$

Requiring evidence of prior informed consent to access taonga species and mātauranga, on its face, seems to benefit Māori. However, without an ABS regime in New Zealand, this would do little. Many who submitted to MBIE on their discussion paper preferred this option, with a disclosure of

308 Sarnoff and Correa, above n 167, at 2 .

309 IGC WIPO Technical Study, above n 7, at 67; and Dawkins, above n 38, at 27

310 Ko Aotearoa Tènei: Te Taumata Tuarua vol 1, above n 3, at 202-205. See also WTO The relationship between the TRIPS Agreement and The Convention on Biological Diversity, above n 6, at 3-7.

311 Ko Aotearoa Tēnei: Te Taumata Tuarua vol 1, above n 3, at 202-205.

312 At 202-205

313 Frankel and Lai, above n 31, at 40; and Lai, above n 75, at 40-41.

314 Frankel and Lai, above n 31, at 40; and Lai, above n 75, at 40-41. 
origin requirement being a useful halfway house until New Zealand established an ABS regime. ${ }^{315}$ Disclosure would achieve little unless New Zealand set up effective mechanisms for competent authorities giving prior informed consent to consult with relevant iwi and hapū and created databases recording iwi and hapū interests in plant species and registering their mātauranga. This is necessary to enable researchers to identify the correct parties for access arrangements but places a burden on Māori to disclose and share their knowledge and place it in the public domain. ${ }^{316}$ The general public would be able to use mātauranga without any obligations to obtain consent or share benefits, unless that use led to a patent application. This would undermine the intent of an ABS regime. In Ko Aotearoa Ténei, the Waitangi Tribunal concluded that kaitiaki needed to be engaged with early in order to protect their interests. ${ }^{317}$ Early engagement would naturally lead to prior informed consent in most cases, especially where the importance of the kaitiaki's interests make such arrangements necessary in order for researchers to continue with their work. ${ }^{318}$ Considering the complex issues that arise in trying to introduce an obligation to disclose ABS arrangements, this is the better view. ABS arrangements are not required in every patent application, nor every patent application that relies on plant species. Finally, one must question whether ABS arrangements are the most effective mechanism for meaningful engagement with iwi and hapu in the patent system. The real effect of such a requirement may simply reduce such interests to "permission" and "benefit", without focusing on iwi and hapū interests on Māori terms.

\section{Disclosure of origin}

If a disclosure of origin requirement were implemented, iwi and hapū would be able to proactively identify inventions that utilise their taonga species and mātauranga. Iwi and hapū would have the opportunity to challenge a patent before it was granted, saving time and expense. ${ }^{319}$ This measure would increase the information provided to IPONZ and assist in assessments on patentability criteria. ${ }^{320}$ In particular, it would help IPONZ identify applications that are relevant to Māori and should be referred to the PMAC for advice. ${ }^{321}$ On its own, a disclosure of origin requirement will not protect the kaitiaki relationship. If an invention is novel and inventive, a patent will be granted irrespective of kaitiaki concerns. For a disclosure of origin requirement to be effective, it must focus on the kaitiaki interest. This needs to be central to design elements such as subject matter, trigger, and

315 MBIE, above n 132, at 4; and University of Auckland Uniservices Ltd, above n 302.

316 WTO The relationship between the TRIPS Agreement and The Convention on Biological Diversity, above $\mathrm{n}$ 6, at 12; and Ko Aotearoa Tēnei: Te Taumata Tuarua vol 1, above n 3, at 203.

317 Ko Aotearoa Tènei: Te Taumata Tuarua vol 1, above n 3, at 200-205.

318 At 205 .

319 At 203

320 MBIE, above n 1, at 20-21.

321 At 20-21. 
sanctions. A disclosure requirement is of little use if it does not capture all taonga species and all mātauranga Māori, or if the trigger for disclosure is too strict; the kaitiaki relationship can still be damaged. ${ }^{322}$ Disclosure may be ineffective if the patent cannot be revoked on the basis of it damaging the kaitiaki relationship iwi and hapu have with those resources. ${ }^{323}$ And yet revocation cannot be the answer in every situation, as acknowledged by the Waitangi Tribunal. ${ }^{324}$ Any definition of subject matter should be broad enough to capture all uses of taonga resources and mātauranga, in order to prioritise the kaitiaki relationship. ${ }^{325}$ It is better to over disclose than risk damage to kaitiaki sliding under the radar. Given the way in which traditional knowledge is used in bioprospecting and research, all contributions of mātauranga should be disclosed. ${ }^{326}$ In contrast, because plants cannot be "owned", a lower threshold may be appropriate. To ensure the kaitiaki relationship with taonga plant species is being considered, uses of genetic resources should be disclosed whenever they are used in an invention. ${ }^{327}$ Sanctions should be discretionary, assessed on a case-by-case basis. ${ }^{328}$ Revocation could be justified on the basis of the ordre public exception, if a clear link was established between the PMAC and the exception - and if the Commissioner was given explicit power to reject a patent to protect the kaitiaki interest. ${ }^{329}$ While a broad approach might be more uncertain or may be slightly more onerous on patent applicants or IPONZ, it is the only way the kaitiaki interest can be appropriately considered within the patent system. In any event, uncertainty may incentivise researchers to proactively interact with kaitiaki well before a patent application, mitigating the risk of revocation. ${ }^{330}$

Any conversation about disclosure should be in the wider context of Māori rights in their mātauranga and taonga resources, and cannot occur without a discussion about how to best honour the Treaty. ${ }^{331}$ This cannot be achieved by a disclosure requirement on its own. Taonga species and mātauranga may still be used in ways that damage the kaitiaki relationship through other modes of commercialisation, and this will continue unless New Zealand implements a bioprospecting

322 Ko Aotearoa Tēnei: Te Taumata Tuarua vol 1, above n 3, at 200-205.

323 At 200-205

324 At 205.

325 At $200-205$.

326 At 200-205; and Te Hunga Rōia Maori o Aotearoa, above n 199.

327 Ko Aotearoa Tēnei: Te Taumata Tuarua vol 1, above n 3, at 200-205.

328 At $200-205$

329 At 200-205.

330 At $200-205$

331 New Zealand Institute of Patent Attorneys, above n 180. 
regime. ${ }^{332}$ IPONZ will still make decisions without receiving advice from the PMAC on relevant patent applications unless the PMAC is given the power to advise on applications of its own volition. ${ }^{333}$ Even if a disclosure requirement is implemented, patents that damage the kaitiaki relationship will still be granted unless the Commissioner of Patents is given explicit power to refuse a patent on this basis. ${ }^{334}$ And over and above this, steps could be taken to avoid leaving consideration of the kaitiaki interest until the patent application stage. Hapu and iwi could be given the option to register their kaitiaki interests in taonga resources. ${ }^{335}$ Researchers, bioprospectors and patent applicants could use this register to proactively ascertain the kaitiaki interests in resources being used. $^{336}$ The PMAC could directly notify iwi and hapū who have registered their interest when they are referred relevant applications. ${ }^{337}$ A similar register could be established for mātauranga Māori. ${ }^{338}$ All of the above were recommendations made by the Waitangi Tribunal in Ko Aotearoa Tennei. ${ }^{339}$ However, even this will not wholly resolve the issue. The discussion around disclosure of origin is part of a much larger issue around mātauranga Māori not being protected by the western intellectual property system. It is not enough to engage with iwi and hapu within existing western frameworks; mātauranga needs to be recognised and protected in and of its own right, on Māori terms. The patent regime is only one example of the exploitation of matauranga that occurs across the intellectual property system. This issue is outside of the scope of this paper, but progress must be made in this area, too, in order to engage with kaitiaki and protect mātauranga.

Without taking a broader view of the kaitiaki relationship, a disclosure of origin requirement would have limited effectiveness. Despite this, it has been eight years since Ko Aotearoa Tēnei, with little progress made. In August 2019, Te Puni Kōkiri (the Ministry of Māori Development) released preliminary proposals for government agencies in response to Wai 262. Part of this would involve creating ministerial oversight groups - one would be related to taonga species and mātauranga Māori. ${ }^{340}$ One of the aims of this group would be to examine how to better give effect to

332 Ko Aotearoa Tènei: Te Taumata Tuarua vol 1, above n 3, at 200-205.

333 At $200-205$.

334 At 200-205.

335 At $200-205$.

336 At $200-205$.

337 Te Rūnanga o Ngāi Tahu, above n 199; and Hoare and Tarasofsky, above n 55, at 160.

338 Ko Aotearoa Tēnei: Te Taumata Tuarua vol 1, above n 3, at 200-205.

339 At 200-205.

340 Te Puni Kōkiri Ministry of Māori Development Wai 262 - Te Pae Tawhiti: The role of the Crown and Māori in making decisions about taonga and mātauranga Māori - Preliminary proposals for Crown organisation (August 2019) at 12-13. 
kaitiakitanga. ${ }^{341}$ The report makes no specific mention of implementing the Waitangi Tribunal recommendations, other than disclosure of origin. In effect, the position in New Zealand remains disappointingly unchanged following Ko Aotearoa Tënei.

\section{CONCLUSION}

A disclosure of origin requirement could be beneficial for Māori. If disclosure were implemented, iwi and hapū would be able to proactively identify inventions that utilise their taonga species and mâtauranga. Iwi and hapu would have the opportunity to challenge a patent before it was granted, saving time and expense. This measure would increase the information provided to IPONZ and assist in assessments on patentability criteria. In particular, it would help IPONZ identify applications that are relevant to Māori and should be referred to the PMAC for advice. However, in order to encourage and enable meaningful interaction with iwi and hapū in the patent regime, Māori interests must be considered on Māori terms - not purely on western intellectual property terms. This means considering the kaitiaki relationship and the best way to protect it. On its own, though, a disclosure of origin requirement will not be effective to protect the kaitiaki relationship. If an invention is novel and inventive, a patent will be granted irrespective of kaitiaki concerns. Numerous changes must be made to the patent regime and surrounding research process in order to provide meaningful engagement with kaitiaki interests.

In Ko Aotearoa Tènei, the Waitangi Tribunal recommended that a bioprospecting regime be implemented; that the PMAC have the ability to advise on patentability and exceptions, particularly the risk to kaitiaki; that the Commissioner of Patents be given explicit permission to refuse a patent if it would damage the kaitiaki relationship in accordance with the ordre public exception; that give iwi and hapu the opportunity to register kaitiaki interests and mātauranga; and that require patent applicants to disclose the taonga species and mātauranga used in their inventions to enable kaitiaki to identify applications that run counter to their obligations. ${ }^{342}$ Despite the report being released eight years ago, little has been done to implement these recommendations. While disclosure of origin is currently being reviewed by MBIE, the discussion paper and options tend to focus on the economic benefit a disclosure requirement could bring and engages in little discussion of the benefits on Māori terms. Consequently, the review gives the appearance of Treaty compliance, but ignores the concepts of meaningful engagement, partnership, and rangatiratanga - on Māori terms.

341 At 21 .

342 Ko Aotearoa Tēnei: Te Taumata Tuarua vol 1, above n 3, at 200-205. 
(2020) 51 VUWLR 